\title{
A review of the mechanisms of mineral- based metabolism in early Earth analog rock-hosted hydrothermal ecosystems
}

\section{Authors: Maximiliano J. Amenabar and Eric S. Boyd}

This is a postprint of an article that originally appeared in World Journal of Microbiology \& Biotechnology on Faebruary 2019. The final version can be found at DOI: $10.1007 /$ s11274-019-2604-2.

Amenabar, Maximiliano J., and Eric S. Boyd. "A review of the mechanisms of mineral-based metabolism in early Earth analog rock-hosted hydrothermal ecosystems." World Journal of Microbiology \& Biotechnology 35, no. 29 (February 2019): 10-16. DOI:10.1007/ s11274-019-2604-2. 
A review of the mechanisms of mineral-based metabolism in early Earth analog rock-hosted hydrothermal ecosystems

Maximiliano J. Amenabar and Eric S. Boyd

Department of Microbiology and Immunology, Montana State University, Bozeman, Montana.

*Author of correspondence: Eric S. Boyd (eboyd@montana.edu)

Department of Microbiology \& Immunology

Montana State University

PO Box 173520

Bozeman, MT 59717

Phone: (406) 994-7046

Fax: (406) 994-4926

Keywords: Elemental sulfur, iron oxide, ferrous iron, sulfide, Archaea, thermophile, hot springs, Yellowstone 


\section{ABSTRACT}

Prior to the advent of oxygenic photosynthesis $\sim 2.8 \mathrm{Ga}$, life was dependent on chemical energy captured from oxidation-reduction reactions involving minerals or substrates generated through interaction of water with minerals. Terrestrial hydrothermal environments host abundant and diverse non-photosynthetic communities and a variety of minerals that can sustain microbial metabolism. Minerals and substrates generated through interaction of minerals with water are differentially distributed in hot spring environments which, in turn, shapes the distribution of microbial life and the metabolic processes that support it. Emerging evidence suggests that terrestrial hydrothermal environments may have played a role in supporting the metabolism of the earliest forms of microbial life. It follows that these environments and their microbial inhabitants are increasingly being studied as analogs of early Earth ecosystems. Here we review current understanding of the processes that lead to variation in the availability of minerals or mineral-sourced substrates in terrestrial hydrothermal environments. In addition, we summarize proposed mechanisms of mineral substrate acquisition and metabolism in microbial cells inhabiting terrestrial hydrothermal environments, highlighting the importance of the dynamic interplay between biotic and abiotic reactions in influencing mineral substrate bioavailability. An emphasis is placed on mechanisms involved in the solubilization, acquisition, and metabolism of sulfur- and iron-bearing minerals, since these elements were likely integrated into the metabolism of the earliest anaerobic cells. 


\section{INTRODUCTION}

Microorganisms and their activities drive global biogeochemical cycles and influence the formation and fate of numerous minerals, both today and throughout the geological past. In many cases, the formation and fate of minerals is an indirect consequence of microbial activity. For example, the formation of iron monosulfide [mackinawite (FeS)] often involves an abiotic reaction between ferrous iron [Fe(II)] and sulfide, either or both of which can be produced by ferric iron $\mathrm{Fe}(\mathrm{III})$ or sulfate $\left(\mathrm{SO}_{4}{ }^{2-}\right)$ reducing organisms, respectively. Likewise, sulfide, produced by microorganisms growing via reduction of oxidized sulfur compounds [e.g., $\mathrm{SO}_{4}{ }^{2-}$, elemental sulfur $\left.\left(\mathrm{S}^{\circ}\right)\right]$, can drive the subsequent abiotic oxidation of $\mathrm{FeS}$ to yield pyrite $\left(\mathrm{FeS}_{2}\right)$ (Drobner et al. 1990; Rickard 1997), the predominant reservoir of iron in the crust (Berner and Berner 1996). Similarly, at low temperature and pressures, microbial exopolymers and activities have been suggested to be the primary means by which calcite or aragonite $\left(\mathrm{CaCO}_{3}\right)$ can be altered to dolomite $\left(\mathrm{MgCa}\left(\mathrm{CO}_{3}\right)_{2}\right)$ (Roberts et al. 2013; Vasconcelos et al. 1995; Zhang et al. 2012; Zhang et al. 2015). Indeed, it has been estimated that $\sim 2800$ of the $\sim 5000$ known minerals on the planet were either directly or indirectly formed because of microbial activity (Hazen et al. 2008).

Of equal importance is the direct use of minerals in oxidation-reduction reactions involving minerals which often results in their oxidative or reductive dissolution. For example, numerous chemolithotrophic microorganisms can couple the oxidation of hydrogen $\left(\mathrm{H}_{2}\right)$ to the reduction of ferric oxyhydroxides or $\mathrm{S}^{\circ}$ and capture and store energy in the form of ATP (Kletzin et al. 2004; Weber et al. 2006). The ferric oxyhydroxides and $\mathrm{S}^{\circ}$ are reductively dissolved to 
Fe(II) and sulfide, respectively, thereby increasing the bioavailability of iron and sulfur for use in cellular biosynthesis or as electron donors for taxa in adjacent and more oxidized environments.

Microbial metabolisms that are dependent on mineral-sourced nutrients are common in both marine and terrestrial environments, surface and subsurface locales, and oxic and anoxic systems (Gadd 2010). Non-photosynthetic contemporary ecosystems are key analogs for understanding the processes that supported life on early Earth prior to the emergence of photosynthetic organisms (Amils et al. 2004; Rothschild and Mancinelli 2001). However, accessible surface environments where photosynthetic communities are excluded and where chemosynthetic communities flourish are rare. These characteristics combine to make the study of the use of mineral-sourced energy in contemporary ecosystems that are minimally influenced by photosynthesis logistically difficult. Fortunately, photosynthetic life is excluded from terrestrial hydrothermal environments with temperatures that exceed $70^{\circ} \mathrm{C}$ in alkaline systems and $54^{\circ} \mathrm{C}$ in acidic systems (Boyd et al. 2012; Boyd et al. 2010; Brock 1967; Cox et al. 2011; Hamilton et al. 2012). Despite the absence of photosynthetic production, abundant and dominant filamentous and sessile communities (Fig. 1) develop in close association with minerals in the higher temperature transects of these springs, suggesting that minerals or products of mineralwater interaction support their metabolism. Moreover, despite hot spring waters being exposed to the atmosphere, the inverse relationship between the solubility of oxygen and temperature (Amend and Shock 2001) allows for anoxic conditions to develop in hot springs and anaerobic microorganisms and processes to flourish (Canganella and Wiegel 2014). Thus, these systems are often regarded as analogs of anoxic hydrothermal systems on early Earth (Djokic et al. 2017; Rothschild and Mancinelli 2001). 
Phylogenetic reconstructions of chemosynthetic microbial inhabitants of high temperature hot spring environments reveal that they often form short lineages that branch near the base or the root of universal trees, indicating that they are among the earliest, yet least evolved of extant microorganisms (Pace 1997; Schwartzman and Lineweaver 2004). Moreover, anaerobic chemotrophs are thought to pre-date aerobic chemotrophs based on both physiological and paleo-geochemical and geological considerations (Farquhar et al. 2000; Lyons et al. 2014; Morris 1975; Thauer et al. 1977). Consistent with these considerations, phylogenetic reconstructions of extant organisms indicate that anaerobic chemotrophs typically pre-date aerobic chemosynthetic chemotrophs, as has been recently demonstrated for the Archaea (Colman et al. 2018). Together, such observations have been interpreted as evidence that thermophilic, chemosynthetic organisms and the processes that sustain them may be reminiscent of those that supported life on early Earth (Djokic et al. 2017; Rothschild and Mancinelli 2001). Moreover, such data have been extended to suggest that high temperature hydrothermal environments might have played an important role in the origin of life (Baross and Hoffman 1985; Corliss et al. 1981; Miller and Bada 1988; Nisbet and Sleep 2001; Shock et al. 1995), a hypothesis that dates to as early as 1924 (Harvey 1924).

High temperature $\left(>70^{\circ} \mathrm{C}\right)$ terrestrial hydrothermal environments exhibit colors attributable to precipitated minerals that are often generated by the activity of microorganisms (Langner et al. 2001; Macur et al. 2013). These include a variety of non-redox active silicate minerals including feldspar, tridymite, kaolinite, opal, and christobalite (Colman et al. 2016) as well as numerous redox active minerals (Allen and Day 1935). Several of the more abundant 
groups of redox active minerals commonly detected in high temperature terrestrial hydrothermal environments include carbonates (aragonite, calcite, siderite), sulfur compounds, $\left(\mathrm{S}^{\circ}, \mathrm{FeS}, \mathrm{FeS}_{2}\right)$, iron oxyhydroxides (ferrihydrite, hematite, limonite), amorphous and crystalline arsenic sulfides (realgar, orpiment), iron arsenate (scorodite), mercury sulfide (cinnabar), manganese oxides (birnessite, hollandite), and sulfate minerals (alunite, jarosite), among others. This review will address current understanding of the geobiological controls on the distribution of select minerals in terrestrial hydrothermal environments and the mechanisms that allow cells to acquire these minerals as substrates to drive their energy metabolisms and to support biosynthesis. We will focus on the Yellowstone National Park (YNP) geothermal system given the extensive history of coupled geological, geochemical, and microbiological investigations conducted on springs that span a wide range of $\mathrm{pH}(1.5$ to 10$)$, temperature (ambient to $93^{\circ} \mathrm{C}$ ), and geochemical and mineralogical compositions [e.g., (Allen and Day 1935)]. The emphasis of this review, as it relates to mechanisms of mineral substrate acquisition by microbial life, will be placed on sulfurand iron-bearing minerals, since transformation of these elements were likely integrated into the metabolism of the earliest anaerobic cells (Philippot et al. 2007; Russell and Martin 2004; Wachtershauser 1988; Wachtershauser 1992; Wachtershauser 2006).

\section{Geological settings of terrestrial magmatic hot springs}

Terrestrial hydrothermal environments are often localized at plate boundaries including those that are divergent (e.g., Iceland) or that are convergent (e.g., Kamchatka, Russia; El Tatio, Chile; Taupo, New Zealand). Hydrothermal environments can also be located away from plate boundaries in areas that are known as hot spots, which are thought to be generated through either 
crustal extension that can allow mantle melts to approach the surface more easily or through mantle plumes (e.g., YNP and Hawaii, United States of America) (Christiansen et al. 2002; Smith and Braile 1994). Regardless of the geological setting associated with terrestrial magmatic hydrothermal systems, they all share three common requirements for their formation: a source of water, a source of heat, and permeable rock strata overlying the heat source (Heasler et al. 2009). Moreover, all hydrothermal systems must be continuously recharged with water.

A schematic of the functioning of continental, volcanic hydrothermal environment is illustrated in Fig. 2, using YNP as the model system. Importantly, non-volcanic continental hydrothermal systems (e.g., Great Basin, Nevada) are thought to function similarly, with the major differences being the heat source and input of magmatic volatiles. Not included in the schematic illustrated in Fig. 2 is the hot spot magma plume, estimated to be $\sim 40 \mathrm{~km}$ beneath the surface of YNP (Huang et al. 2015). This magma plume is transferring heat (and volatiles) to a basalt magma partial melt ( $\sim 46,000 \mathrm{~km}^{3}$ in volume) at $\sim 45-20 \mathrm{~km}$ depth which is transferring heat to an upper rhyolitic magma partial melt $\left(\sim 10,000 \mathrm{~km}^{3}\right.$ in volume). The upper chamber is depicted in Fig. 2.

Based on current understanding, meteoric water is thought to infiltrate the geothermal system in a recharge area, which in the case of YNP is largely concentrated just outside of the North and Eastern Park boundary (Kharaka et al. 2002; Rye and Truesdell 2007). Water percolates through fractures and/or pores in rocks and into the subsurface to form a single deep "parent" water body. The temperature of this parent water body in YNP has been estimated to be up to $360^{\circ} \mathrm{C}$ with a chloride $\left(\mathrm{Cl}^{-}\right)$concentration of $310 \mathrm{mg} \mathrm{L}^{-1}$ (McKenzie and Truesdell 1977) 
and a $\mathrm{SO}_{4}{ }^{2-}$ concentration of 73 to $98 \mathrm{mg} \mathrm{L}^{-1}$ (Nordstrom et al. 2009). The parent water body is infused with oxidized volcanic gases, including sulfur dioxide $\left(\mathrm{SO}_{2}\right)$ and hydrochloric acid $(\mathrm{HCl})$ which, upon contact with water at high temperature, are thought to contribute the $\mathrm{SO}_{4}{ }^{2-}$ estimated above via $\mathrm{SO}_{2}$ disproportionation (Reaction 1) and the $\mathrm{Cl}^{-}$estimated above via $\mathrm{HCl}$ ionization, respectively (McKenzie and Truesdell 1977; Truesdell and Fournier 1976; White et al. 1971).

$$
4 \mathrm{SO}_{2}+4 \mathrm{H}_{2} \mathrm{O} \rightarrow 3 \mathrm{H}_{2} \mathrm{SO}_{4}+\mathrm{H}_{2} \mathrm{~S} \quad \text { Reaction } 1
$$

Heat-induced pressure or density differences allow these fluids to ascend to the surface along a fluid pathway that is controlled by fractures and faults. As such, the majority of hot spring activity in YNP is concentrated along the edge of the main ring fracture associated with the 0.6 mya caldera forming eruption and at the margins of the two resurgent domes, the Mallard Lake and the Sour Creek.

\section{Geological controls on hot spring water geochemical composition}

As hydrothermal fluids ascend to near surface local aquifers that feed hot springs, geysers, and fumaroles, they can be altered by processes such as water-rock interaction, boiling, and mixing with near-surface groundwater (Lowenstern et al. 2012; Nordstrom et al. 2009). A primary control on the composition of hot spring waters is the process of decompressional boiling which can separate fluids into a liquid and a vapor phase in what is oftentimes referred to as phase separation (Fournier 1989; Nordstrom et al. 2009; Truesdell and Fournier 1976; White et al. 1971). Most evidence from YNP hot springs suggests that phase separation is a multiplestage process (incomplete separation of liquid and vapor) that produces results intermediate between single-stage and continuous phase separation (Truesdell and Fournier 1976). Volatiles 
in hydrothermal fluids are likely to be partitioned to the vapor phase during phase separation (Fournier 1989; Nordstrom et al. 2009). These volatiles include $\mathrm{H}_{2}$, helium (He), methane $\left(\mathrm{CH}_{4}\right)$ and hydrogen sulfide $\left(\mathrm{H}_{2} \mathrm{~S}\right)$, among other gases (Lowenstern et al. 2015). As described in more detail below, the behavior and fate of $\mathrm{H}_{2} \mathrm{~S}$ during phase separation exerts significant influence on the geochemical composition of hot spring waters (Lindsay et al. 2018; Nordstrom et al. 2009), and of particular relevance to this review, the availability of minerals to support microbial metabolism. It follows that an important consideration of the hydrothermal fluids undergoing phase separation is the $\mathrm{pH}$ and temperature of parent fluids, given that the $\mathrm{pKa}$ of $\mathrm{H}_{2} \mathrm{~S} / \mathrm{HS}^{-}$is 6.5 at $100^{\circ} \mathrm{C}$ (Amend and Shock 2001). Thus, depending on the $\mathrm{pH}$ and temperature of the parent hydrothermal fluids in question, a fraction of the total $\mathrm{H}_{2} \mathrm{~S} / \mathrm{HS}^{-}$may partition during initial boiling events, potentially leaving substantial $\mathrm{HS}^{-}$in solution that is then available for processing during subsequent boiling episodes (multi-stage phase separation model). Subsequent phase separation events would be expected to progressively deplete the $\mathrm{H}_{2} \mathrm{~S} / \mathrm{HS}^{-}$remaining in the liquid phase. Acidification of fluids as they ascend to the surface (described below) or as they mix with acidified meteoric fluids in the form of perched aquifers (Nordstrom et al. 2009), which themselves could be acidic in particular in areas around the Norris Geyser Basin (White et al. 1988), may affect the speciation of $\mathrm{H}_{2} \mathrm{~S} / \mathrm{HS}^{-}$. This in turn may alter the amount of $\mathrm{H}_{2} \mathrm{~S}$ that is volatized in subsequent phase separation events, potentially leading to its enrichment and thus acidification of waters in certain geographic locations or springs. It is generally thought that the waters that boil in deeper portions of the YNP system are near neutral (Fournier 1989; White et al. 1971). 
Following phase separation, the vapor is free to migrate toward the surface where it can condense and interact with oxygen $\left(\mathrm{O}_{2}\right)$-rich meteoric fluids. The near surface oxidation of $\mathrm{H}_{2} \mathrm{~S} \mathrm{HS}^{-}$with $\mathrm{O}_{2}$ can generate acidity in the form of sulfuric acid (Nordstrom et al. 2009), a process that is thought to be mediated by microorganisms (Colman et al. 2018). Thus, springs that are sourced with waters that are influenced by vapor phase input tend to be acidic and enriched in $\mathrm{SO}_{4}{ }^{2-}$ (Fournier 1989; Nordstrom et al. 2005; Xu et al. 1998). Such systems are common in the north to north central (Norris Geyser Basin, Central Plateau) and eastern (Hot Spring Basin, Mud Volcano, Crater Hills) edges of the caldera (Lowenstern et al. 2015). In contrast, systems receiving substantial liquid phase input tend to be alkaline and rich in $\mathrm{Cl}^{-}$. These types of systems tend to be concentrated in the Lower, Midway, and Upper Geyser Basin on the western side of the caldera (Lowenstern et al. 2015). Thus, phase separation of hydrothermal fluids results in the concentration of spring types geographically but that fit within a bimodal distribution of hot spring $\mathrm{pH}$ types, with the two spring types centered on sulfuric acid (vapor phase influenced) and bicarbonate (liquid phase influenced) buffered springs (Amenabar et al. 2015). Variable mixing and dilution of spring waters can further affect their composition and differences in the underlying bedrock and the interaction of these rocks with hydrothermal fluids can further alter spring chemistry (Fournier 1989).

\section{Geological controls on the distribution of redox active minerals in hot springs}

The processes described above, in particular phase separation, are also likely to influence the availability of minerals in hot springs, including those that play a prominent role in supporting the microbial metabolism of thermophiles such as $\mathrm{S}^{\circ}$ and iron (hydr)oxides. The 
deposition of $\mathrm{S}^{\circ}$ in hot springs most likely begins with oxidation of $\mathrm{H}_{2} \mathrm{~S}$, which is thought to be primarily sourced to the parent hydrothermal aquifer by $\mathrm{SO}_{2}$ disproportionation (Reaction 1). For reasons discussed above, $\mathrm{H}_{2} \mathrm{~S}$ can be enriched in vapor phase influenced hot spring waters (Nordstrom et al. 2009). The kinetics of abiotic oxidation of $\mathrm{H}_{2} \mathrm{~S}$ with $\mathrm{O}_{2}$ are several orders of magnitude slower than biotic oxidation (Chen and Morris 1972; Luther et al. 2011; Zhang and Millero 1993), specifically in solutions with $\mathrm{pH}<6.0$ (Chen and Morris 1972) where the predominant, uncharged $\mathrm{H}_{2} \mathrm{~S}$ species is less reactive (Millero 1986). However, these experiments have only been performed at low temperature $\left(<45^{\circ} \mathrm{C}\right)$ and the role of abiotic reactions in the oxidation of $\mathrm{H}_{2} \mathrm{~S}$ at higher temperatures is not known, especially at lower $\mathrm{pH}$. The Arrhenius law would predict an increase in the rate of abiotic $\mathrm{H}_{2} \mathrm{~S}$ oxidation with increasing temperature, to the extent that $\mathrm{O}_{2}$ in solution does not become limiting given its decreasing solubility at elevated temperature (Shock et al. 2010). Trace metals (e.g., vanadate, Fe(III), cupric copper) have been shown to enhance rates of abiotic $\mathrm{H}_{2} \mathrm{~S}$ oxidation (Steudel 1996), and thus must also be considered when assessing the relative contribution of biotic and abiotic processes in $\mathrm{H}_{2} \mathrm{~S}$ oxidation.

Regardless of whether oxidation is biotically or abiotically catalyzed, the process typically proceeds through a series of intermediate sulfur species that includes thiosulfate $\left(\mathrm{S}_{2} \mathrm{O}_{3}{ }^{2-}\right.$ ), in particular when $\mathrm{O}_{2}$ is limiting (Chen and Morris 1972; Xu et al. 1998). Sulfide oxidation has also been suggested to directly result in formation of $\mathrm{S}^{\circ}$ (Fuseler and Cypionka 1995). At circumneutral $\mathrm{pH}, \mathrm{S}_{2} \mathrm{O}_{3}{ }^{2-}$ is thermodynamically stable and can serve as an oxidant or reductant for chemical reactions. However, at acidic $\mathrm{pH}(\mathrm{pH}<4.0), \mathrm{S}_{2} \mathrm{O}_{3}{ }^{2-}$ is unstable ( $\mathrm{Xu}$ and Schoonen $1995)$ and disproportionates to form solid-phase $\mathrm{S}^{\circ}$ and sulfite $\left(\mathrm{SO}_{3}{ }^{2-}\right)$, the latter of which is also 
unstable and hydrolyzes to form $\mathrm{SO}_{4}{ }^{2-}$ and protons (Nordstrom et al. 2004). Irrespective of the mechanism by which it is formed, the $\mathrm{S}^{\circ}$ formed from $\mathrm{H}_{2} \mathrm{~S}$ oxidation accumulates in many acid $(<4.0)$ geothermal springs due to its slow reactivity with water below $100^{\circ} \mathrm{C}$ (Fournier 1989 ; Kamyshny 2009) and thus represents a key electron donor or acceptor capable of supporting microbial metabolism (Boyd et al. 2009).

Protons generated from $\mathrm{H}_{2} \mathrm{~S} / \mathrm{S}^{\circ}$ oxidation in vapor-phase-influenced environments can also contribute to the release of metals from altered host rock (Ball et al. 2010), including Fe(II) that can then be oxidized leading to formation of soluble Fe(III) ions and Fe(III) containing solid phases. The iron (hydr)oxide mats that form at Chocolate Pots (pH 5.8 to 6.0 at source), a vapor influenced mildly acidic spring just south of Norris Geyser Basin (Allen and Day 1935), is perhaps the most well studied iron (hydr)oxide mat in a hot spring in YNP if not the world. This spring has been studied extensively from both the mineralogical [e.g., (Wade et al. 1999; Wu et al. 2013)] and the biological perspectives [e.g., (Fortney et al. 2016; Fortney et al. 2018a; Fortney et al. 2018b; Pierson and Parenteau 2000; Trouwborst et al. 2007)]. Current understanding suggests that Fe(II) in the source vent waters of Chocolate Pots is rapidly oxidized by $\mathrm{O}_{2}$ that is in supersaturating concentrations due to the activity of oxygenic Cyanobacteria. The precipitates at Chocolate Pots comprise a variety of iron (hydr)oxides including goethite ( $\alpha$ $\mathrm{FeOOH})$ and hematite $\left(\alpha-\mathrm{Fe}_{2} \mathrm{O}_{3}\right)$, and the carbonate mineral siderite $\left(\mathrm{FeCO}_{3}\right)$. The iron (hydr)oxides can serve as electron acceptors in microbial metabolism whereas siderite could serve as an electron donor or potentially even an inorganic carbon source. However, to the authors knowledge, siderite has not been extensively examined as an electron donor or inorganic carbon source in this or other YNP springs. 
In more acidic hot springs $(\mathrm{pH}<4.0)$ such as "Dragon Spring" in the Norris Geyser Basin (Langner et al. 2001), abiotic oxidation of $\mathrm{Fe}(\mathrm{II})$ with $\mathrm{O}_{2}$ is kinetically inhibited (Edwards et al. 2000; Edwards et al. 1999; Johnson and Hallberg 2005). In these systems, Fe(II) oxidation is catalyzed by the activity of thermoacidophilic Archaea and Bacteria (Kozubal et al. 2008; Kozubal et al. 2012), which form iron oxide containing mineralized microbial mats (Fig. 1). In addition to microbial cells, the mats can be comprised of amorphous iron oxyhydroxides, ferrihydrite, goethite, and hematite (Kozubal et al. 2012; Langner et al. 2001). Importantly in acidic springs, such as "Dragon Spring", Fe oxide mats tend to not form until $\mathrm{H}_{2} \mathrm{~S}$ is oxidized with concomitant $\mathrm{S}^{\circ}$ deposition or volatilized from the system, likely due to the more favorable energetics associated with microbial oxidation of $\mathrm{H}_{2} \mathrm{~S}$ or $\mathrm{S}^{\circ}$ with $\mathrm{O}_{2}$ when compared to $\mathrm{Fe}(\mathrm{II})$ with $\mathrm{O}_{2}$ (Amend and Shock 2001). These Fe(III) oxides or ions can serve as a source of oxidant for $\mathrm{Fe}(\mathrm{III})$ reducing taxa.

While Fe(II) is more effectively leached from bedrock by acidic spring waters than circumneutral to alkaline spring waters and is typically in higher concentrations in the former spring type (Ball et al. 2010), Fe has been detected in springs of the latter type. This includes aqueous Fe(III) in the source waters of Perpetual Spouter $\left(\mathrm{pH} 7.1,84^{\circ} \mathrm{C}\right)($ Ball et al. 2010) and in the solid phase precipitates in the source of the spring (Inskeep et al. 2005). In this spring, concentrations of $\mathrm{Fe}(\mathrm{III})$ were higher than what is expected based on the solubility of a variety of iron oxides under these conditions, indicating that the Fe(III) may be complexed by organic ligands thereby increasing its solubility (Kraemer 2004). Moreover, given that Fe(II) reacts quickly with $\mathrm{O}_{2}$ in solutions with circumneutral to alkaline $\mathrm{pH}$ and that are high temperature 
(Morgan and Lahav 2007), it is likely that oxidation and formation of Fe(III) oxides in such systems is abiotic. Regardless, these Fe(III) oxides can serve as electron acceptors to support microbial metabolism.

\section{Metabolism of $\mathrm{S}^{\circ}$ in hydrothermal environments}

\subsection{Geomicrobiology of $S^{\circ}$}

$\mathrm{S}^{\circ}$, formed from the incomplete oxidation of $\mathrm{H}_{2} \mathrm{~S}$, is a common redox active mineral in hot springs (Amenabar and Boyd 2018; Boyd and Druschel 2013; Boyd et al. 2007; Colman et al. 2016). Precipitation of $\mathrm{S}^{\circ}$ often leads to an $\mathrm{S}^{\circ}$ depositional zone of characteristic yellow color (Amenabar and Boyd 2018; Langner et al. 2001) (Fig. 1). $S^{\circ}$ is generally more abundant in acidic hot springs (Boyd et al. 2007; Inskeep et al. 2013), since these springs are influenced to a greater degree by vapor phase input that is enriched in $\mathrm{H}_{2} \mathrm{~S}$ relative to liquid phase input (Nordstrom et al. 2009) and the $\mathrm{pH}$ and Eh of these springs is within the stability field of $\mathrm{S}^{\circ}$ (Rickard and Luther 2007). Indeed, a taxonomically diverse array of thermoacidophiles have been shown to use $\mathrm{S}^{\circ}$ in their energy metabolism, either as an electron donor (sulfur oxidation) (Amenabar et al. 2017; Friedrich et al. 2001; Huber and Prangishvili 2006) or as an electron acceptor (sulfur reduction) (Amenabar et al. 2017; Boyd and Druschel 2013; Boyd et al. 2007; Boyd et al. 2009; Huber and Prangishvili 2006). In many cases, organisms that integrate $S^{\circ}$ into their energy metabolism have been shown to be numerically dominant in communities inhabiting acidic hot springs communities (Boyd and Druschel 2013; Boyd et al. 2007; Boyd et al. 2009; Colman et al. 2016; Colman et al. 2018; Friedrich et al. 2001; Giaveno et al. 2013; Muyzer and Stams 2008; Power et al. 2018; Segerer et al. 1986; Urschel et al. 2016; Yoshida et al. 2006). 
Thermoacidophiles within the archaeal order Sulfolobales, which are physiologically versatile and grow as facultative aerobes with the ability to oxidize or reduce $\mathrm{S}^{\circ}$ (Amenabar et al. 2018; Giaveno et al. 2013; Huber and Stetter 2015), are commonly detected in acidic thermal environments. In anoxic acidic thermal springs, organisms within the archaeal order Desulfurococcales, which typically use $\mathrm{S}^{\circ}$ as an oxidant, are commonly detected.

Despite the lower occurrence of $\mathrm{S}^{\circ}$ in neutral/alkaline environments, Archaea and Bacteria have been suggested to respire $\mathrm{S}^{\circ}$ under these conditions using either $\mathrm{CO}_{2}$ (chemolithoautotrophs) or organic substrates (chemoorganotrophs) as carbon source and electron donor (Amenabar et al. 2015; Canfield and Raiswell 1999; Ghosh and Dam 2009). However, when compared to acidophiles, far less is known about the mechanisms of $\mathrm{S}^{\circ}$ reduction in organisms inhabiting circumneutral to alkaline hot springs (Amenabar et al. 2015; Eder and Huber 2002; Ghosh and Dam 2009). As described in more detail in section 5.2 below, it is possible, if not likely, that organisms in these environments are utilizing a more soluble source of $\mathrm{S}^{\circ}$ such as polysulfide ( $\mathrm{S}_{\mathrm{x}}{ }^{2-}$ where $\mathrm{X}$ is the number of sulfur atoms). $\mathrm{S}_{\mathrm{x}}{ }^{2-}$ are formed by reaction of HS$^{-}$with $\mathrm{S}^{\circ}$ (Steudel and Eckert 2003) and are stable under sulfidic, circumneutral $(\mathrm{pH}>6.0)$ conditions (Schauder and Muller 1993).

Reduction of $\mathrm{S}^{\circ}\left(\right.$ or $\mathrm{S}_{\mathrm{x}}{ }^{2-}$ ) has been suggested to be an ancient process (Canfield and Raiswell 1999; Stetter et al. 1990; Stetter and Gaag 1983) and it is worth exploring the basis of this argument for the purposes of this review. Fractionation of sulfur isotopes $\left({ }^{34} \mathrm{~S} /{ }^{\beta 2} \mathrm{~S}\right)$ during microbial $\mathrm{S}^{\circ}$ (or $\mathrm{S}_{\mathrm{x}}{ }^{2-}$ ) reduction to $\mathrm{H}_{2} \mathrm{~S} / \mathrm{HS}^{-}$is minimal or close to zero (Gest and Hayes 1984; Kaplan and Rittenberg 1962; Surkov et al. 2012). This makes it difficult to use sulfur isotopes in 
minerals preserved in the rock record to date when this metabolic process may have emerged. Yet, isotopic evidence from marine chert-barite deposits from the Dresser Formation, Australia suggest that $\mathrm{S}^{\circ}$ was at least available as a substrate at $3.5 \mathrm{Ga}$, with evidence indicating that it was disproportionated not necessarily reduced (Philippot et al. 2007). Importantly, the barite veins that were analyzed in the aforementioned study have been suggested to represent conduits for hydrothermal fluid circulation and may have been deposited in a volcanic caldera like environment (Van Kranendonk 2006). These observations, combined with the widespread prevalence of $\mathrm{S}^{\circ}$ reducing thermophilic organisms in both the bacterial and archaeal domain (Amenabar et al. 2015; Canfield and Raiswell 1999; Ghosh and Dam 2009), including deeply rooted methanogens (Stetter and Gaag 1983), suggests that energy conservation via $\mathrm{S}^{\circ}$ reduction is likely to be a primitive process. Moreover, the prevalence of hyperthermophiles that branch near the root of the universal tree of life, and that support their energy metabolism through $\mathrm{S}^{\circ}$ reduction, may suggest that this process emerged in a hyperthermophile inhabiting a hydrothermal environment early in Earth history (Schauder and Kröger 1993; Stetter et al. 1990).

$\mathrm{S}^{\circ}$ can also serve as a reductant in the energy metabolism of a variety of microorganisms, including those that inhabit hot springs (Amenabar et al. 2017). While the majority of work on $\mathrm{S}^{\circ}$ oxidation has focused on aerobic organisms (Ghosh and Dam 2009; Kletzin et al. 2004), $\mathrm{S}^{\circ}$ oxidation has also been demonstrated in anaerobes, in particular those that can reduce soluble or insoluble Fe(III). Among characterized organisms from high temperature habitats, the coupling of $\mathrm{S}^{\circ}$ oxidation with $\mathrm{Fe}(\mathrm{III})$ reduction has thus far only been demonstrated in members of the archaeal genus Acidianus (Amenabar et al. 2017; Giaveno et al. 2013). Like the biological reduction of $\mathrm{S}^{\circ}$ to $\mathrm{H}_{2} \mathrm{~S} / \mathrm{HS}^{-}$, the biological oxidation of $\mathrm{S}^{\circ}$ to $\mathrm{SO}_{4}{ }^{2-}$ imparts a minimal 
fractionation on sulfur isotopes (Zerkle et al. 2009), again, making it difficult to use sulfur isotopes preserved in minerals in the rock record to gauge when this process might have emerged. However, evidence for $\mathrm{S}^{\circ}$ in environmental systems as early as $3.5 \mathrm{Ga}$ (e.g., (Philippot et al. 2007; Van Kranendonk 2006)) and Fe(III) in ancient banded iron formations, including those as old as $3.8 \mathrm{Ga}$ in the Isua of West Greenland (e.g., as reviewed in (Gole and Klein 1981)), indicates that the substrates to support anaerobic $\mathrm{S}^{\circ}$ oxidation coupled with $\mathrm{Fe}(\mathrm{III})$ reduction were available at these times, albeit not necessarily in the same location. Moreover, the prevalence of archaeal and bacterial organisms that support their energy metabolism through the reduction of Fe(III), including those that grow at extremely high temperature (Kashefi and Lovley 2003), has been used to suggest that Fe(III) reduction is among the most ancient of metabolic processes, perhaps predating the process of $S^{\circ}$ reduction (Vargas et al. 1998). This conclusion is partially supported by isotopic data from banded iron and other iron-containing formations that together indicate that the process of Fe(III) reduction has an early origin, with current data suggesting this process to be at least as old as $3.1 \mathrm{Ga}$ (as reviewed in (Johnson et al. 2008)). Importantly, it is not yet clear from these observations what the electron donor supporting Fe(III) reduction would have been during this time.

$\mathrm{S}^{\circ}$ can also simultaneously serve as an electron donor and acceptor in a process called sulfur disproportionation (Muyzer and Stams 2008). This process is thought to be ancient, with ${ }^{34} \mathrm{~S} /{ }^{32} \mathrm{~S}$ isotopic fractionation data indicative of this process in hydrothermal barite deposits dated to $3.5 \mathrm{Ga}$ (Philippot et al. 2007). Despite the prevalence of $\mathrm{S}^{\circ}$ in hydrothermal environments, both today and in Earth's geologic past, only two thermophilic organisms with the ability to disproportionate $S^{\circ}$ have been described (Amenabar and Boyd 2018; Slobodkin et al. 2012). The 
lack of cultured representatives capable of $\mathrm{S}^{\circ}$ disproportionation from hydrothermal environments may be due to difficulties in obtaining cultures of these organisms due to thermodynamic constraints (Amenabar and Boyd 2018) imposed on this type of metabolism by high levels of $\mathrm{H}_{2} \mathrm{~S} / \mathrm{HS}^{-}$or $\mathrm{SO}_{4}{ }^{2-}$ that commonly associate with acidic thermal environments (Amenabar et al. 2015). Nonetheless, a recently described archaeal strain from a $\mathrm{S}^{\circ}$ rich acidic hydrothermal environment in YNP was shown to oxidize, reduce, and disproportionate $\mathrm{S}^{\circ}$ (Amenabar and Boyd 2018), pointing to the key role of $\mathrm{S}^{\circ}$ in sustaining the energy metabolism of thermoacidophiles in these environments. Importantly, microorganisms with the ability to incorporate $\mathrm{S}^{\circ}$ into their energy metabolism are common outside of hydrothermal environments as well. As will be described in the following section, the mechanisms that allow for the use of $\mathrm{S}^{\circ}$, whether it be oxidatively, reductively, or disproportionatively, are unlikely to be dependent on temperature. Thus, discussion will focus on those organisms that are the target of this review, thermophiles.

\subsection{Mechanism of $\mathrm{S}$ reduction, oxidation, and disproportionation in thermophiles}

$\mathrm{S}^{\circ}$ can be effectively described as insoluble in water $\left(478 \mathrm{nM}\right.$ at $\left.80^{\circ} \mathrm{C}\right)$ (Kamyshny 2009). Thus, in order to use this mineral for use as a substrate in energy metabolism, microorganisms have to access it by either direct contact or by using a more "hydrophilic" or "colloidal" form (Schauder and Kroger 1993). It has been shown that aqueous solutions containing $\mathrm{H}_{2} \mathrm{~S} / \mathrm{HS}^{-}$can dissolve $\mathrm{S}^{\circ}$ through the formation of polysulfides $\left(\mathrm{S}_{\mathrm{x}}{ }^{2-}\right)$ (Giggenbach 1972; Kleinjan et al. 2005), with the rate of $\mathrm{S}_{\mathrm{x}}{ }^{2-}$ formation dependent on the $\mathrm{pH}$ of the solution; $\mathrm{pH}$ influences the stability of 
$\mathrm{S}_{\mathrm{x}}{ }^{2-}$, as described below. This is an important consideration since $\mathrm{S}_{\mathrm{x}}{ }^{2-}$ can act as an auto-catalyst accelerating the dissolution of $S^{\circ}$ (Giggenbach 1972; Kleinjan et al. 2005).

$\mathrm{S}_{\mathrm{x}}{ }^{2-}$ ions are unbranched chains of sulfur atoms, with the number and structure of those linear sulfur chains being dependent on the $\mathrm{pH}$ of the solution (Kamyshny et al. 2007; Steudel and Eckert 2003). At neutral to intermediate $\mathrm{pH}$ conditions, $\mathrm{S}_{6}{ }^{2}-\mathrm{S}_{5}{ }^{2-}$, and $\mathrm{S}_{4}{ }^{2-}$ ions dominate the solution. However, under acidic conditions, polysulfide ions are not stable and rapidly disproportionate (Boyd and Druschel 2013; Giggenbach 1972; Kamyshny et al. 2003; Kleinjan et al. 2005). The concentration of $\mathrm{S}_{\mathrm{x}}{ }^{2-}$ in aqueous solutions is dependent on $\mathrm{pH}$, the concentration of sulfide, and the availability of $\mathrm{S}^{\circ}$. In aqueous solutions with $\mathrm{pH}>6.0$, measurements of $\mathrm{S}_{\mathrm{x}}{ }^{2-}$ formed from $\mathrm{S}^{\circ}$ in the presence of abundant sulfide indicates that $\mathrm{S}_{\mathrm{x}}{ }^{2-}$ is present at sufficient concentration to support sulfur reduction at the growth conditions of sulfur reducing Bacteria and Archaea (Schauder and Kröger 1993; Schauder and Muller 1993). Growth assays indicate that $\mathrm{S}_{\mathrm{x}}{ }^{2-}$ supports the growth of sulfur reducing neutrophilic microorganisms such as the bacterium Wolinella succinogenes (Klimmek et al. 1991) and the archaeon Pyrococcus furiosus (Blumentals et al. 1990). These observations, in addition to the mechanisms of $\mathrm{S}_{\mathrm{x}}{ }^{2-}$ formation and $\mathrm{S}_{\mathrm{x}}{ }^{2-}$ stability outlined above, suggest that $\mathrm{S}^{\circ}$ reducing microorganisms inhabiting circumneutral pH environments are likely using $\mathrm{S}_{\mathrm{x}}{ }^{2-}$ as terminal electron acceptor (TEA) (Fig. 3A). Indeed, a recent study identified a membrane bound oxidoreductase, termed MBX (Schut et al. 2007; Wu et al. 2018), that is involved in reduction of sulfane bonds during $\mathrm{S}_{\mathrm{x}}{ }^{2-}$ reduction in the hyperthermophile $P$. furiousus. Thus, $\mathrm{S}_{\mathrm{x}}{ }^{2-}$ is likely the soluble intermediate for $\mathrm{S}^{\circ}$ reduction for microorganisms growing at $\mathrm{pH}>6.0$ (Findlay 2016; Schauder and Muller 1993). 
Intriguingly, like $\mathrm{S}^{\circ}$ reducers inhabiting circumneutral $\mathrm{pH}$ environments, $\mathrm{S}^{\circ}$-reducing thermoacidophiles also appear to be reducing a soluble source of $\mathrm{S}^{\circ}$. This was originally reported for the $\mathrm{S}^{\circ}$-reducing thermoacidophilic crenarchaeote Acidilobus sulfurireducens (Desulfurococcales), which was shown to not associate with bulk $\mathrm{S}^{\circ}$ during $\mathrm{S}^{\circ}$ dependent growth (Boyd et al. 2007). However, the amount of $\mathrm{S}^{\circ}$ dissolved as $\mathrm{S}_{\mathrm{x}}{ }^{2-}$ decreases dramatically with decreasing $\mathrm{pH}$, due to the instability of $\mathrm{S}_{\mathrm{x}}{ }^{2-}$ in acidic solutions (Schauder and Muller 1993). In aqueous solutions with $\mathrm{pH}<6.0, \mathrm{~S}_{\mathrm{x}}{ }^{2-}$ (formed via reactions between sulfide $\left(\mathrm{H}_{2} \mathrm{~S} / \mathrm{HS}^{-}\right)$and $\left.\mathrm{S}^{\circ}\right)$ disproportionate to yield $\mathrm{H}_{2} \mathrm{~S}$ and soluble nanoparticulate $\mathrm{S}^{\circ}$ rings $\left(\mathrm{S}_{8}\right)$ according reaction 2:

$$
2 \mathrm{~S}_{5}{ }^{2-}+4 \mathrm{H}^{+} \rightarrow \alpha-\mathrm{S}_{8}{ }^{\circ}+2 \mathrm{H}_{2} \mathrm{~S} \quad \text { Reaction } 2
$$

The decreased stability of $\mathrm{S}_{\mathrm{x}}{ }^{2-}$ in acidic solutions relative to alkaline solutions suggests that microorganisms inhabiting acidic environments are unlikely to be using $\mathrm{S}_{\mathrm{x}}{ }^{2-}$ as TEA but rather are likely using nanocrystalline $\mathrm{S}^{\circ}$ formed through $\mathrm{S}_{\mathrm{x}}{ }^{2-}$ disproportionation (reaction 2) (Boyd and Druschel 2013). This was demonstrated by sequestering bulk $\mathrm{S}^{\circ}$ powder inside dialysis membranes of different pore sizes to limit the access of cells to the surface of $\mathrm{S}^{\circ}$ during growth. Under this growth condition, the thermoacidophile A. sulfurireducens did not require direct access to $\mathrm{S}^{\circ}$ to use it as a TEA (Boyd and Druschel 2013), indicating that these cells were using a more soluble form of $\mathrm{S}^{\circ}$ (nanoparticulate $\mathrm{S}^{\circ}$ ). Moreover, decreased $\mathrm{S}^{\circ}$ reduction activity and cell production were observed when $\mathrm{S}^{\circ}$ was sequestered in dialysis membranes with increasingly small pore sizes, an observation that was attributed to the nanoparticulate $\mathrm{S}^{\circ}$ existing in a range of particle sizes (Boyd and Druschel 2013). Nanoparticulate $\mathrm{S}^{\circ}$ rapidly aggregates/coarsens into larger particles due to hydrophilic interactions (Boyd and Druschel 2013; Garcia and Druschel 2014) and thus was suggested to be the soluble form of $\mathrm{S}^{\circ}$ that served as electron acceptor. 
Founded on an extensive literature database describing the inorganic chemistry of $\mathrm{S}_{\mathrm{x}}{ }^{2-}$ (Giggenbach 1972; Kamyshny 2009; Kamyshny et al. 2003; Schauder and Muller 1993; Steudel 1996; Steudel and Eckert 2003), a model involving a series of biological/abiological feedbacks was put forth to describe the formation and fate of nanoparticulate $\mathrm{S}^{\circ}$ in cultures of $A$. sulfurireducens (Boyd and Druschel 2013). Here, $\mathrm{H}_{2} \mathrm{~S} / \mathrm{HS}^{-}$resulting from the biological reduction of $\mathrm{S}^{\circ}$, generates soluble linear chains of $\mathrm{S}_{\mathrm{x}}{ }^{2-}$ through abiotic nucleophilic attack on bulk (stacked) $\mathrm{S}^{\circ}$ rings. The thermodynamic instability of $\mathrm{S}_{\mathrm{x}}{ }^{2-}$ in the $\mathrm{pH} 3.0$ cultivation medium used to cultivate $A$. sulfurireducens leads to its rapid, abiotic disproportionation yielding soluble $\mathrm{S}_{8}{ }^{\circ}$ molecular rings that rapidly aggregate or coarsen, reaching average particle diameters of 400 nm within several minutes of their disproportionation (Boyd and Druschel 2013; Garcia and Druschel 2014). These reactions were confirmed to take place in the absence of cells. Thus, the abiotic rates of $\mathrm{S}_{\mathrm{x}}{ }^{2-}$ production and disproportionation, the former of which is dependent on the rate of $\mathrm{H}_{2} \mathrm{~S}$ produced by biological activity, and the kinetics of coarsening are likely to generate a distribution of soluble $\mathrm{S}^{\circ}$ particle sizes during the incubation period.

Consistent with this model, similar growth experiments with the thermoacidophile Acidianus strain DS80 indicated that the electron acceptor (i.e., nanoparticulate $\mathrm{S}^{\circ}$ ) that supported growth also exhibited an apparent size dependence (Amenabar and Boyd 2018). These results suggest that a similar mechanism involving biological and abiological feedbacks (Fig. 3A) is likely supporting $\mathrm{S}^{\circ}$ dependent growth in strain DS80 (Sulfolobales) and $A$. sulfurireducens (Desulfurococcales) (Boyd et al. 2007) and may extend to other thermoacidophiles such as the thermoacidophilic bacterium Thermovibrio ammonificans (Jelen 
et al. 2018). Importantly, application of environmental voltametric techniques by Lorenson and colleagues (Lorenson 2006) and chromatographic methods by Kamyshny and colleagues (Kamyshny et al. 2014) reveal the presence of soluble $S^{\circ}$ colloids or nanoparticles in a variety of sulfur rich, hydrothermal environments in YNP including Evening Primrose (pH 6.5) and Cinder Pool ( $\mathrm{pH} 4.0-5.0)$. These environments also feature elevated abundances of organisms affiliated with Acidilobus and Acidianus (Colman et al. 2016; Urschel et al. 2016; Urschel et al. 2015), suggesting that the process that allows for solubilization and use of $\mathrm{S}^{\circ}$ in pure cultures may also be operational in sulfur rich hot springs inhabited by these strains.

Based on the intermediates involved in the proposed mechanism of $\mathrm{S}^{\circ}$ reduction (Fig. 3A) and their thermodynamic stabilities, the requirement for direct access to $S^{\circ}$ is going to differ depending on whether cells are using the mineral as an oxidant, a reductant, or both as a reductant and oxidant (disproportionation). This was demonstrated using Acidianus strain DS80 as a model (Amenabar and Boyd 2018). Like Acidianus cells grown via $\mathrm{S}^{\circ}$ reduction, those grown via $\mathrm{S}^{\circ}$ disproportionation did not require direct access to the mineral for it to be used in its energy metabolism. This suggests that the $\mathrm{H}_{2} \mathrm{~S}$ formed through disproportionation of $\mathrm{S}^{\circ}$ functioned to solubilize $\mathrm{S}^{\circ}$ through a mechanism like what is described above for $\mathrm{S}^{\circ}$ reducing cells. However, unlike DS80 cells reducing or disproportionating $\mathrm{S}^{\circ}$, cells that were grown via $\mathrm{S}^{\circ}$ oxidation required direct access to the mineral. The requirement for direct contact to $\mathrm{S}^{\circ}$ for use as an electron donor is consistent with microscopic observations of cultures of Acidianus spp. (Amenabar, unpublished data) and other $\mathrm{S}^{\circ}$ oxidizing crenarchaeotes such as Sulfolobus spp. that were shown to be attached to $S^{\circ}$ crystals in both lab cultures (both genera) and in samples collected from various hot spring environments (Sulfolobus spp. only) (Brock et al. 
1972). Further evidence that direct access to bulk $S^{\circ}$ is required for $S^{\circ}$ to serve as electron donor comes from a study of Acidianus strain DS80, whereby growth was not observed when access to bulk $\mathrm{S}^{\circ}$ was restricted by placing it inside of dialysis membranes (Amenabar and Boyd 2018). This observation further substantiates the proposed mechanism that allows cells access to $\mathrm{S}^{\circ}$ under reducing conditions since the $\mathrm{H}_{2} \mathrm{~S} / \mathrm{HS}^{-}$(the product of $\mathrm{S}^{\circ}$ reduction and disproportionation) needed to initiate the series of abiotic reactions that solubilize $S^{\circ}$ (Boyd and Druschel 2013) was incapable of being produced under oxic growth conditions (Figs. 3A, B).

$\mathrm{S}^{\circ}$ oxidation in thermoacidophiles involves the cytoplasmic sulfur oxygenase reductase (SOR) complex which disproportionates $\mathrm{S}^{\circ}$ to yield $\mathrm{SO}_{3}{ }^{2-}$ and $\mathrm{H}_{2} \mathrm{~S}$. The $\mathrm{SO}_{3}{ }^{2-}$ produced can then be assimilated via APS reductase or further oxidized to $\mathrm{SO}_{4}{ }^{2-}$ via a membrane bound sulfide:acceptor oxidoreductase. Through a series of non-enzymatic steps involving $\mathrm{S}^{\circ}$ as an intermediate, $\mathrm{H}_{2} \mathrm{~S}$ is thought to be converted to $\mathrm{S}_{2} \mathrm{O}_{3}{ }^{2-}$ and oxidized via a thiosulfate:quinone oxidoreductase (Kletzin et al. 2004). SOR is common among thermoacidophiles within the Sulfolobales genera Acidianus and Sulfolobus. Little is known of putative mechanisms involved in the oxidation of $\mathrm{S}^{\circ}$ in organisms inhabiting neutral to alkaline environments (Ghosh and Dam 2009; Sorokin et al. 2001). This is likely due to the predominant form of $\mathrm{S}^{\circ}$ being $\mathrm{S}_{\mathrm{x}}{ }^{2-}$ under these conditions since the intermediate that is largely responsible for $\mathrm{S}^{\circ}$ precipitation during $\mathrm{H}_{2} \mathrm{~S} \mathrm{HS}^{-}$oxidation, $\mathrm{S}_{2} \mathrm{O}_{3}{ }^{2-}$, is stable at $\mathrm{pH}>4.0$ (Xu et al. 1998).

Two primary mechanisms of $\mathrm{S}^{\circ}$ reduction that involve membrane-bound enzyme complexes have been described to date. In chemolithotrophic $\mathrm{S}^{\circ}$ reducing organisms that use $\mathrm{H}_{2}$ as electron donor (e.g, Thermoproteus tenax, A. ambivalens or Acidianus strain DS80), a 
respiratory system involving a membrane-bound sulfur reductase complex (SRE) and a membrane-bound $[\mathrm{NiFe}]$-hydrogenase, similar to those found in the mesophilic $\mathrm{S}^{\circ}$ reducing bacterium W. succinogenes (Amenabar et al. 2018; Hedderich et al. 1998; Laska et al. 2003), is involved. Electron transfer between the membrane bound [NiFe]-hydrogenase involved in oxidizing $\mathrm{H}_{2}$ and $\mathrm{SRE}$ involved in $\mathrm{S}^{\circ}$ reduction is thought to involve the hydride carrier sulfolobusquinone. Specificity of the hydrogenase or SRE for sulfolobusquinone has been suggested to constrain these organisms to obligately reduce $\mathrm{S}^{\circ}$ with only $\mathrm{H}_{2}$ as electron donor (Amenabar et al., 2018). A second cytoplasmic SRE (SRE2) complex has been identified in $\mathrm{S}^{\circ}$ reducing organisms that use organic substrates as electron donor [(Amenabar et al. 2018), and references therein]. The cytosolic location of SRE2 is thought to allow for reduced electron carriers from organic carbon oxidation via the Kreb's cycle (e.g., NADPH) to reduce $\mathrm{S}^{\circ}$.

A second prevalent mechanism of $\mathrm{S}^{\circ}\left(\mathrm{S}_{\mathrm{X}}{ }^{2-}\right)$ reduction has been described in heterotrophic hyperthermophilic Archaea, primarily within the Thermococcales (Euryarchaeota) order. The proteins comprising this multisubunit oxidoreductase complex, termed MBX, resemble components of energy converting [NiFe]-hydrogenases and NADH dehydrogenase (Complex I) (Schut et al. 2013). This has led to the suggestion that MBX represents an evolutionary "intermediate" between early evolving $\mathrm{H}_{2}$ based respiratory metabolisms and those using oxidants with much higher potential (Boyd et al. 2014; Schut et al. 2016). Neutrophilic hyperthermophiles, such as Pyrococcus and Thermococcus, use MBX to reduce the sulfane bonds in $\mathrm{Sx}^{2-}$ (Wu et al. 2018). Homologs of MBX have also been identified in a variety of crenarchaeotes that commonly inhabit hot spring environments, including a variety of neutrophilic members of the Desulfurococcales (Schut et al. 2013). The apparent lack of MBX 
homologs among acidophiles and the detection of MBX homologs among neutrophiles is consistent with the prevalence and thermodynamic stability of $\mathrm{Sx}^{2-}$ at these $\mathrm{pH}$ values. This suggests that the stabilities of sulfur compounds may have played a role in the emergence and evolution of enzymatic mechanisms to utilize these substrates in energy metabolism.

\section{Metabolism of Fe in hydrothermal environments}

\subsection{Geomicrobiology of Fe}

In addition to $\mathrm{S}^{\circ}$, common minerals capable of supporting microbial metabolism in hot springs include a variety of iron (hydr)oxides (Fig.1) (Fortney et al. 2016; Inskeep and McDermott 2005; Kashefi et al. 2008b; Langner et al. 2001; Lovley et al. 2004; Slobodkin 2005; Slobodkina et al. 2012), which result from the oxidation of Fe(II) with oxygen (Inskeep et al. 2004; Kozubal et al. 2008). Dissimilatory iron reduction (DIR) plays a key role on the biogeochemistry of iron in both moderate and higher temperature environments (Lovley et al. 2004) and has been suggested to be one of the earliest forms of microbial respiration (Vargas et al. 1998). Microorganisms with the capacity to conserve energy from DIR are phylogenetically dispersed throughout the bacterial and archaeal domains and this metabolism has been suggested to be a highly conserved trait among hyperthermophiles (Lovley 2004; Lovley et al. 2004). See text in section 5.1 for additional discussion on the primitive nature of DIR and the organisms that catalyze this process.

Iron availability is low in most oxic and circumneutral environments. This is not necessarily due to low total iron content but rather is due to the low solubility and the slow 
dissolution kinetics of iron bearing minerals (Kraemer 2004). Therefore, in order to use iron (hydr)oxides in DIR, microorganisms had to evolve mechanisms to transfer metabolic electrons to insoluble solid phases. Perhaps the most well studied bacterial models for understanding the mechanisms of iron mineral reduction/oxidation in microbial metabolism under mesophilic conditions are Geobacter spp. and Shewenalla spp. (Fredrickson et al. 2008; Lovley et al. 2004; Nealson and Scott 2006; Shi et al. 2007; Shi et al. 2009). However, thermophiles with the ability to reduce iron bearing minerals have also been described (Amenabar and Boyd 2018; Kashefi and Lovley 2000; Kashefi et al. 2008b; Slobodkin et al. 1997; Slobodkin et al. 1999), yet the mechanisms involved in the respiration of these solid minerals are not well understood. Most of our knowledge on iron (hydr)oxide respiration in hyperthermophiles comes from studies of the neutrophilic genus Pyrobaculum, members of which are metabolically flexible and are widely distributed in circumneutral to alkaline terrestrial hydrothermal environments [(Feinberg and Holden 2006), and references therein].

Under high temperature and acidic conditions, our understanding of iron (hydr)oxide reduction is less complete, likely because thermoacidophilic iron reducers have only just been reported (Amenabar et al. 2017; Giaveno et al. 2013; Kozubal et al. 2012; Reysenbach et al. 2006; Yoshida et al. 2006) and detailed characterizations of the mechanisms of insoluble iron reduction are not yet available. Arguably, members from the thermoacidophilic archaeal genus Acidianus could be considered as a counterpart to the hyperthermophilic, neutrophilic Pyrobaculum due to their widespread distribution in terrestrial hydrothermal environments (Huber and Stetter 2015), their metabolic flexibility (Amenabar et al. 2018), and several physiological studies reporting the capacity of some members of this genus to respire iron 
(hydr)oxide minerals (Amenabar and Boyd 2018; Giaveno et al. 2013; Yoshida et al. 2006).

Similar to what has been described for many mesophilic iron reducers (Lovley 1991), thermophilic DIR organisms tend to prefer poorly crystalline Fe(III) (hydr)oxides (e.g., ferrihydrite) over more crystalline Fe(III) (hydr)oxides such as goethite or hematite (Amenabar and Boyd 2018; Greene et al. 1997; Kashefi and Lovley 2000). This suggests that constraints imposed by the low solubility and bioavailability of iron (hydr)oxide mineral and/or the mechanisms of DIR could be similar between mesophilic and thermophilic organisms.

\subsection{Mechanism of Fe reduction during microbial metabolism}

Two general mechanisms of DIR have been described in mesophilic organisms (Hernandez and Newman 2001; Weber et al. 2006), including the use of chelators or siderophores that solubilize minerals facilitating their transport into the cell (Gralnick and Newman 2007) and extracellular electron transfer (EET) based mechanisms (Marsili et al. 2008; Reguera et al. 2005; Shi et al. 2016). Although data indicating secretion of compounds that might act as siderophores or chelators in thermophilic DIR organisms have not been reported, the presence of these types of compounds in the environment might stimulate the reduction of iron bearing minerals by increasing the bioavailability of Fe(III) (Gralnick and Newman 2007; Kraemer 2004). Here, we focus on EET mechanisms of DIR.

EET mechanisms vary in whether direct access to the surface of the solid is required and if so, the mechanisms by which cells transfer electrons to the mineral surface (Fig. 4). Three different EET mechanisms have been proposed in mesophilic iron reducers, several of which 
appear to be shared with their thermophilic counterparts. The first mechanism involves a direct electron transfer between a membrane bound electron carrier, such as outer-membrane c-type cytochromes, and the solid iron bearing mineral (Fig. 4A) (Beliaev et al. 2001; Magnuson et al. 2001; Myers and Myers 2001; Richardson 2000). Although this mechanism has not been directly reported in thermophilic iron reducers, it is possible that some (hyper)thermophiles, such as Pyrobaculum islandicum (Kashefi et al. 2008a), rely on a similar mechanism where direct contact is required. This is suggested by electron micrographs showing intimate contact between P. islandicum and poorly crystalline Fe(III) oxides during DIR-dependent growth. Similarly, physiological experiments with iron minerals sequestered inside dialysis membranes indicate that Pyrobaculum calidifontis likely requires direct contact with insoluble iron (hydr)oxide for DIRdependent growth (Feinberg et al. 2008). Interestingly, unlike mesophilic iron reducers, where $c$ type cytochromes are integral components of cellular membranes during electron transport to the solid mineral, $P$. islandicum is not thought to code for $c$-type cytochromes indicating a different mechanism of electron transport during DIR (Childers and Lovley 2001). In contrast to $P$. islandicum, P. calidifontis does code for a putative membrane-bound polyheme $c$-type cytochrome similar to the polyheme $c$-type cytochromes found in the mesophilic bacterial genera Shewanella and Geobacter (Feinberg et al. 2008).

The second EET mechanism of DIR involves soluble electron shuttles such as flavins and quinones (Fig. 4B), where direct contact with the mineral is not required for Fe reduction, such as the case of Shewanella (Newman and Kolter 2000; von Canstein et al. 2008). Similar to Shewanella, P. aerophilum and Pyrobaculum arsenaticum also can reduce iron (hydr)oxides without direct contact to the iron mineral (Feinberg et al. 2008). To this end, P. aerophilum and 
P. arsenaticum might use a similar mechanism involving an electron shuttle as an extracellular mediator of iron reduction. Indeed, this mechanism of EET has been suggested for P. aerophilum (Feinberg and Holden 2006).

The third EET mechanism of DIR involves the use of an extracellular component such as pili as nanowires that could transfer electrons from the bacterial cell to the solid phase (Fig. 4C), such as has been widely described in Geobacter (Gorby et al. 2006; Reguera et al. 2005). Although the physical properties conferring conductivity to microbial nanowires have been controversial, it has been recently suggested that overlap of the pi-pi orbitals of aromatic amino acids in the structural protein PilA from Geobacter imparts metallic-like conductivity to the structures, independent of the presence of polyheme $c$-type cytochrome (Malvankar et al. 2015). Recently it has been shown that the thermophilic bacterium Carboxydothermus ferrireducens also required direct contact to reduce poor crystalline Fe(III) oxides at moderately elevated temperatures $\left(65^{\circ} \mathrm{C}\right)$ (Gavrilov et al. 2012). A putatively physiological role of pili-like appendages in the extracellular electron transfer to the iron mineral was suggested for this strain. Homologs of putative porin-cytochrome complexes, which have been hypothesized to be involved in EET and iron reduction in Geobacter (Liu et al. 2014), have been identified in iron oxide mats recovered from Chocolate Pots hot spring in YNP (Fortney et al. 2016; Fortney et al. 2018a; Fortney et al. 2018b). These homologs were related to divergent Ignavibacterium- and Thermodesulfovibrio-like populations, among others.

Most of the work focused on DIR in thermophiles has been conducted on neutrophilic strains, where iron (hydr)oxides can represent prevalent sources of electron acceptors. However, 
the otherwise low solubility of iron (hydr)oxide minerals at neutral $\mathrm{pH}$, a condition that likely drove the evolution of numerous mechanisms of EET or Fe(III) acquisition, might be overcome in acidic conditions since iron solubility is inversely proportional to $\mathrm{pH}$ (Kraemer 2004).

Consistent with this notion, it has been shown that Fe(II) and Fe(III) are more soluble in acidic waters (Johnson et al. 2012) and are enriched in many acidic hot springs (Ball et al. 2010). As such, many acidic springs have iron (hydr)oxide depositional zones resulting from extensive oxidation of Fe(II) and precipitation of Fe(III) (Beam et al. 2016; Inskeep and McDermott 2005; Inskeep et al. 2004; Kozubal et al. 2008; Langner et al. 2001). Despite these observations, only a few thermoacidophiles have been shown to couple Fe(III) reduction to growth in hightemperature acidic conditions (Amenabar et al. 2017; Giaveno et al. 2013; Kozubal et al. 2012; Yoshida et al. 2006). Moreover, if these thermoacidophiles reduce solid phase iron (hydr)oxides or if they reduce Fe(III) released by acid-promoted dissolution of these minerals is not known for all described strains. It has been suggested that iron oxide reducing thermoacidophilic microorganisms [e.g., Acidicaldus sp. (Kozubal et al. 2012)] might reduce solubilized Fe(III) ions or ion complexes generated during acid leaching of the solid phase.

Reports that Acidianus strain DS80 can grow via DIR without direct access to the mineral surface, albeit with slower rates and slower generation times than when provided with access to the surface, suggests that these cells can either directly reduce solid phase iron minerals or promote their dissolution leading to greater availability of Fe(III) ions for reduction (Amenabar and Boyd 2018). Consistent with the notion of cells reducing a solubilized form of Fe and not the bulk mineral, microscopic imaging of DIR DS80 cells grown with ferrihydrite reveals that they are not intimately associated with the mineral (Amenabar et al. 2017). In addition to ferrihydrite, 
this was found to be true for DIR DS80 cells grown with a variety of Fe(III) minerals as TEA, including goethite, and hematite (Amenabar and Boyd 2018). Importantly, however, rates of DIR in DS80 cultures varied depending on the Fe(III) mineral that served as TEA. Higher rates of reduction were observed with poorly crystalline ferrihydrite than with goethite, and higher rates of reduction were observed with goethite than crystalline hematite. These observations are consistent with the equilibrium solubilities of the different iron sources tested: ferrihydrite $\left(\mathrm{K}_{\mathrm{s}}=\right.$ $3.55)>$ goethite $\left(\mathrm{K}_{\mathrm{s}}=0.36\right)>$ hematite $\left(\mathrm{K}_{\mathrm{s}}=-0.53\right)($ Kraemer 2004). However, with these data it is difficult to deconvolute whether the decrease in Fe reduction rate with increased mineral crystallinity is due to an increased ease by which electrons can be deposited into poorly crystalline mineral lattices, as has been shown for a Shewanella alga strain (Roden and Zachara 1996), or if this is due to increased reduction of soluble Fe(III) ions due to differences in mineral solubility. Nevertheless, DS80 cells grew via DIR with ferrihydrite sequestered in dialysis membranes, albeit at slower rates than when provided direct access to the mineral (Amenabar and Boyd 2018). Taken together, these data indicate that under acidic conditions, such as those present in the environments where Acidianus DS80 or other thermoacidophiles inhabit, microorganisms are poised to reduce soluble Fe(III) ions leached from precipitated iron minerals through a proton-promoted dissolution mechanism (Kraemer 2004). It is possible that intimate contact with the surface of the mineral allows for electron exchange between $\mathrm{Fe}(\mathrm{II}), \mathrm{Fe}(\mathrm{III})$ ions, and/or the Fe(III) solid phase, which may influence the rate of iron oxide dissolution.

\section{Concluding remarks}


Numerous lines of evidence from a variety of perspectives point to a role for high temperature, hydrothermal conditions in supporting the earliest forms of microbial life. In its early stages, microbial life was likely dependent on chemical sources of energy in the form of oxidation-reduction reactions involving minerals or substrates generated by interaction of minerals with water, the extent of which can be enhanced at high temperature depending on the reaction. Terrestrial, volcanic hydrothermal systems integrate subsurface and surface processes that together result in extensive geochemical variation, including variable distributions of minerals and mineral-sourced substrates capable of supporting microbial metabolism. These environments also host non-photosynthetic communities that comprise early evolving microbial lineages. To this end, terrestrial, volcanic hydrothermal environments represent convenient analogs for developing an understanding of the role of minerals in supporting early forms of microbial life.

Microorganisms and their activities have a profound influence on the formation and fate of minerals in hydrothermal environments. The microbial influence on mineral formation and dissolution can take place through indirect (abiotic) or direct (biotic) mechanisms, both of which are important to take into consideration when thinking about global element cycles or more localized element cycling such as within a given hydrothermal system. This is certainly the case when considering the iron and sulfur cycles, where feedbacks between abiotic and biotic processes not only influence the formation and fate of minerals, they also influence element availability for use in microbial metabolism. These considerations, in turn, influence the distribution of microorganisms in hydrothermal environments in contemporary settings and may 
have influenced the origin of these metabolic processes and the taxa supported by them in early Earth environments.

\section{Acknowledgements}

This work was supported by a NSF grant (EAR-1820658) to ESB. MJA acknowledges support from the CONICYT Becas-Chile fellowship program.

\section{References}

Allen ET, Day AL (1935) Hot springs of the Yellowstone national park. Carnegie Institution of Washington, Washington

Amenabar MJ, Boyd ES (2018) Mechanisms of mineral substrate acquisition in a thermoacidophile Appl Environ Microbiol 84 doi:10.1128/AEM.00334-18

Amenabar MJ, Colman DR, Poudel S, Roden EE, Boyd ES (2018) Electron acceptor availability alters carbon and energy metabolism in a thermoacidophile Environ Microbiol 20:25232537 doi: $10.1111 / 1462-2920.14270$

Amenabar MJ, Shock EL, Roden EE, Peters JW, Boyd ES (2017) Microbial substrate preference dictated by energy demand rather than supply Nat Geosci 10:577-581

doi:10.1038/ngeo2978

Amenabar MJ, Urschel MR, Boyd ES (2015) Metabolic and taxonomic diversification in continental magmatic hydrothermal systems. In: Bakermans C (ed) Microbial Evolution under Extreme Conditions. De Gruyter, Berlin, pp 57-96

Amend JP, Shock EL (2001) Energetics of overall metabolic reactions of thermophilic and hyperthermophilic Archaea and Bacteria FEMS Microbiol Rev 25:175-243 doi:10.1016/S0168-6445(00)00062-0

Amils R et al. (2004) Importance of chemolithotrophy for early life on Earth: the Tinto River (Iberian Pyritic Belt) case. In: Seckbach J (ed) Origins. Cellular origin, life in extreme habitats and astrobiology, vol 6. Springer, Dordrecht, pp 463-480

Ball JW, McMleskey RB, Nordstrom DK (2010) Water-chemistry data for selected springs, geysers, and streams in Yellowstone National Park, Wyoming, 2006-2008. US Geological Survey, 
Baross JA, Hoffman SE (1985) Submarine hydrothermal vents and associated gradient environments as sites for the origin and evolution of life Origins Life Evol B 15:327-345 doi:10.1007/Bf01808177

Beam JP, Bernstein HC, Jay ZJ, Kozubal MA, deM Jennings R, Tringe SG, Inskeep WP (2016) Assembly and succession of iron oxide microbial mat communities in acidic geothermal springs Front Microbiol 7 doi:10.3389/fmicb.2016.00025

Beliaev AS, Saffarini DA, McLaughlin JL, Hunnicutt D (2001) MtrC, an outer membrane decahaem c cytochrome required for metal reduction in Shewanella putrefaciens MR-1 Mol Microbiol 39:722-730 doi:10.1046/j.1365-2958.2001.02257.x

Berner EK, Berner RA (1996) Global environment: water, air, and geochemical cycles. Prentice Hall, Englewood Cliffs, New Jersey

Blumentals II, Itoh M, Olson GJ, Kelly RM (1990) Role of polysulfides in reduction of elemental sulfur by the hyperthermophilic archaebacterium Pyrococcus furiosus Appl Environ Microbiol 56:1255-1262

Boyd ES, Druschel GK (2013) Involvement of intermediate sulfur species in biological reduction of elemental sulfur under acidic, hydrothermal conditions Appl Environ Microbiol 79:2061-2068 doi:10.1128/Aem.03160-12

Boyd ES, Fecteau KM, Havig JR, Shock EL, Peters JW (2012) Modeling the habitat range of phototrophs in Yellowstone National Park: toward the development of a comprehensive fitness landscape Front Microbiol 3 doi:10.3389/fmicb.2012.00221

Boyd ES, Hamilton TL, Spear JR, Lavin M, Peters JW (2010) [FeFe]-hydrogenase in Yellowstone National Park: evidence for dispersal limitation and phylogenetic niche conservatism ISME J 4:1485-1495 doi:10.1038/ismej.2010.76

Boyd ES et al. (2007) Isolation, characterization, and ecology of sulfur-respiring Crenarchaea inhabiting acid-sulfate-chloride-containing geothermal springs in yellowstone national park Appl Environ Microbiol 73:6669-6677 doi:10.1128/Aem.01321-07

Boyd ES, Leavitt WD, Geesey GG (2009) $\mathrm{CO}_{2}$ uptake and fixation by a thermoacidophilic microbial community attached to precipitated sulfur in a geothermal spring Appl Environ Microbiol 75:4289-4296 doi:10.1128/Aem.02751-08

Boyd ES, Schut GJ, Adams MW, Peters JW (2014) Hydrogen metabolism and the evolution of biological respiration Microbe 9:361-367

Brock TD (1967) Life at high temperatures. Science 158:1012-1019 doi:10.1126/science.158.3804.1012

Brock TD, Brock KM, Belly RT, Weiss RL (1972) Sulfolobus: New genus of sulfur-oxidizing bacteria living at low $\mathrm{pH}$ and high temperature Arch Mikrobiol 84:54-68 doi:10.1007/Bf00408082 
Canfield DE, Raiswell R (1999) The evolution of the sulfur cycle Am J Sci 299:697-723 doi:10.2475/ajs.299.7-9.697

Canganella F, Wiegel J (2014) Anaerobic thermophiles Life (Basel) 4:77-104 doi:10.3390/life4010077

Chen KY, Morris JC (1972) Kinetics of oxidation of aqueous sulfide by $\mathrm{O}_{2}$ Environ Sci Technol 6:529-537 doi:10.1021/es60065a008

Childers SE, Lovley DR (2001) Differences in Fe (III) reduction in the hyperthermophilic archaeon, Pyrobaculum islandicum, versus mesophilic Fe (III)-reducing bacteria FEMS Microbiol Lett 195:253-258 doi:10.1111/j.1574-6968.2001.tb10529.x

Christiansen RL, Foulger GR, Evans JR (2002) Upper-mantle origin of the Yellowstone hotspot Geol Soc Am Bull 114:1245-1256 doi:10.1130/00167606(2002)114<1245:Umooty $>2.0 . \mathrm{Co} ; 2$

Colman DR, Feyhl-Buska J, Robinson KJ, Fecteau KM, Xu H, Shock EL, Boyd ES (2016) Ecological differentiation in planktonic and sediment-associated chemotrophic microbial populations in Yellowstone hot springs Fems Microbiol Ecol 92:fiw137 doi:10.1093/femsec/fiw137

Colman DR, Poudel S, Hamilton TL, Havig JR, Selensky MJ, Shock EL, Boyd ES (2018) Geobiological feedbacks and the evolution of thermoacidophiles ISME J 12:225-236 doi:10.1038/ismej.2017.162

Corliss JB, Baross J, Hoffman S (1981) An hypothesis concerning the relationships between submarine hot springs and the origin of life on earth Oceanologica Acta, Special issue (0399-1784)

Cox A, Shock EL, Havig JR (2011) The transition to microbial photosynthesis in hot spring ecosystems Chem Geol 280:344-351 doi:10.1016/j.chemgeo.2010.11.022

Djokic T, Van Kranendonk MJ, Campbell KA, Walter MR, Ward CR (2017) Earliest signs of life on land preserved in ca. $3.5 \mathrm{Ga}$ hot spring deposits Nat Commun 8 doi:ARTN $1526310.1038 /$ ncomms 15263

Drobner E, Huber H, Wachtershauser G, Rose D, Stetter KO (1990) Pyrite formation linked with hydrogen evolution under anaerobic conditions Nature 346:742-744 doi: $10.1038 / 346742 \mathrm{a} 0$

Eder W, Huber R (2002) New isolates and physiological properties of the Aquificales and description of Thermocrinis albus sp nov. Extremophiles 6:309-318 doi:10.1007/s00792001-0259-y

Edwards KJ, Bond PL, Gihring TM, Banfield JF (2000) An archaeal iron-oxidizing extreme acidophile important in acid mine drainage Science 287:1796-1799

doi:10.1126/science.287.5459.1796 
Edwards KJ et al. (1999) Geomicrobiology of pyrite $\left(\mathrm{FeS}_{2}\right)$ dissolution: case study at Iron Mountain, California Geomicrobiology Journal 16:155-179

Farquhar J, Bao HM, Thiemens M (2000) Atmospheric influence of Earth's earliest sulfur cycle Science 289:756-758 doi:10.1126/science.289.5480.756

Feinberg LF, Holden JF (2006) Characterization of dissimilatory $\mathrm{Fe}(\mathrm{III})$ versus $\mathrm{NO}_{3}{ }^{-}$reduction in the hyperthermophilic archaeon Pyrobaculum aerophilum J Bacteriol 188:4163-4163 doi:10.1128/Jb.00515-06

Feinberg LF, Srikanth R, Vachet RW, Holden JF (2008) Constraints on anaerobic respiration in the hyperthermophilic archaea Pyrobaculum islandicum and Pyrobaculum aerophilum Appl Environ Microbiol 74:396-402 doi:10.1128/Aem.02033-07

Findlay AJ (2016) Microbial impact on polysulfide dynamics in the environment FEMS Microbiol Lett 363 doi:10.1093/femsle/fnw103

Fortney NW, He S, Converse BJ, Beard BL, Johnson CM, Boyd ES, Roden EE (2016) Microbial $\mathrm{Fe}(\mathrm{III})$ oxide reduction potential in Chocolate Pots hot spring, Yellowstone National Park Geobiology 14:255-275 doi:10.1111/gbi.12173

Fortney NW, He SM, Converse BJ, Boyd ES, Roden EE (2018a) Investigating the composition and metabolic potential of microbial communities in Chocolate Pots hot springs Front Microbiol 9:2075 doi:10.3389/fmicb.2018.02075

Fortney NW, He SM, Kulkarni A, Friedrich MW, Holz C, Boyd ES, Roden EE (2018b) Stable isotope probing for microbial iron reduction in Chocolate Pots hot spring, Yellowstone National Park Appl Environ Microbiol 84:e02894-17 doi:UNSP e028941710.1128/AEM.02894-17

Fournier RO (1989) Geochemistry and dynamics of the Yellowstone National Park hydrothermal system Annu Rev Earth P1 Sc 17:13-53 doi:10.1146/annurev.ea.17.050189.000305

Fredrickson JK et al. (2008) Towards environmental systems biology of Shewanella Nat Rev Microbiol 6:592-603 doi:10.1038/nrmicro1947

Friedrich CG, Rother D, Bardischewsky F, Quentmeier A, Fischer J (2001) Oxidation of reduced inorganic sulfur compounds by bacteria: Emergence of a common mechanism? Appl Environ Microbiol 67:2873-2882 doi:10.1128/Aem.67.7.2873-2882.2001

Fuseler K, Cypionka H (1995) Elemental sulfur as an intermediate of sulfide oxidation with oxygen by Desulfobulbus propionicus Arch Microbiol 164:104-109 doi: $10.1007 / \mathrm{bf0} 2525315$

Gadd GM (2010) Metals, minerals and microbes: geomicrobiology and bioremediation Microbiol-Sgm 156:609-643 doi:10.1099/mic.0.037143-0 
Garcia AA, Druschel GK (2014) Elemental sulfur coarsening kinetics Geochem T 15:11 doi:10.1186/s12932-014-0011-Z

Gavrilov SN, Lloyd JR, Kostrikina NA, Slobodkin AI (2012) Fe(III) oxide reduction by a grampositive thermophile: Physiological mechanisms for dissimilatory reduction of poorly crystalline $\mathrm{Fe}$ (III) oxide by a thermophilic gram-positive bacterium Carboxydothermus ferrireducens Geomicrobiol J 29:804-819 doi:10.1080/01490451.2011.635755

Gest BFH, Hayes JM (1984) Isotope effects associated with the anaerobic oxidation of sulfide by the purple photosynthetic bacterium, Chromatium vinosum FEMS Microbiol Lett 22:283287

Ghosh W, Dam B (2009) Biochemistry and molecular biology of lithotrophic sulfur oxidation by taxonomically and ecologically diverse bacteria and archaea FEMS Microbiol Rev 33:999-1043 doi:10.1111/j.1574-6976.2009.00187.x

Giaveno MA, Urbieta MS, Ulloa JR, Toril EG, Donati ER (2013) Physiologic versatility and growth flexibility as the main characteristics of a novel thermoacidophilic Acidianus strain isolated from copahue geothermal area in Argentina Microb Ecol 65:336-346 doi:10.1007/s00248-012-0129-4

Giggenbach W (1972) Optical-spectra and equilibrium distribution of polysulfide ions in aqueous-solution at 20 Degrees Inorg Chem 11:1201-1207 doi:10.1021/ic50112a009

Gole MJ, Klein C (1981) Banded iron-formations through much of Precambrian time J Geol 89:169-183

Gorby YA et al. (2006) Electrically conductive bacterial nanowires produced by Shewanella oneidensis strain MR-1 and other microorganisms P Natl Acad Sci USA 103:1135811363 doi:10.1073/pnas.0604517103

Gralnick JA, Newman DK (2007) Extracellular respiration Mol Microbiol 65:1-11 doi:10.1111/j.1365-2958.2007.05778.x

Greene AC, Patel BKC, Sheehy AJ (1997) Deferribacter thermophilus gen nov, sp nov, a novel thermophilic manganese- and iron-reducing bacterium isolated from a petroleum reservoir Int J Syst Bacteriol 47:505-509 doi:10.1099/00207713-47-2-505

Hamilton TL, Vogl K, Bryant DA, Boyd ES, Peters JW (2012) Environmental constraints defining the distribution, composition, and evolution of chlorophototrophs in thermal features of Yellowstone National Park Geobiology 10:236-249 doi:10.1111/j.14724669.2011.00296.x

Harvey RB (1924) Enzymes of thermal algae Science 60:481-482 doi:10.1126/science.60.1560.481

Hazen RM et al. (2008) Mineral evolution Am Mineral 93:1693-1720 doi:10.2138/am.2008.2955 
Heasler HP, Jaworowski C, Foley D (2009) Geothermal systems and monitoring hydrothermal features. In: Rob Young LN (ed) Geological Monitoring. The Geological Society of America, Boulder, Colorado, pp 105-140

Hedderich R, Klimmek O, Kroger A, Dirmeier R, Keller M, Stetter KO (1998) Anaerobic respiration with elemental sulfur and with disulfides FEMS Microbiol Rev 22:353-381 doi:10.1111/j.1574-6976.1998.tb00376.x

Hernandez ME, Newman DK (2001) Extracellular electron transfer Cell Mol Life Sci 58:15621571 doi:10.1007/P100000796

Huang HH, Lin FC, Schmandt B, Farrell J, Smith RB, Tsai VC (2015) The Yellowstone magmatic system from the mantle plume to the upper crust Science 348:773-776 doi:10.1126/science.aaa5648

Huber H, Prangishvili D (2006) Sulfolobales. In: Dworkin M, Falkow S, Rosenberg E, Schleifer K-H, Stackebrandt E (eds) Prokaryotes: A Handbook on the Biology of Bacteria, vol 3. Springer, New York, pp 23-51. doi:10.1007/0-387-30743-5_3

Huber H, Stetter KO (2015) Acidianus. In: Bergey's Manual of Systematics of Archaea and Bacteria. John Wiley \& Sons, Inc., pp 1-5

Inskeep W, McDermott T (2005) Geomicrobiology of acid-sulfate-chloride springs in Yellowstone National Park. In: Inskeep WP, McDermott T (eds) Geothermal biology and geochemistry in Yellowstone National Park. Montana State University Publications, Bozeman, Montana, pp 143-162

Inskeep WP, Ackerman GG, Taylor WP, Kozubal M, Korf S, Macur RE (2005) On the energetics of chemolithotrophy in nonequilibrium systems: case studies of geothermal springs in Yellowstone National Park Geobiology 3:297-317 doi:10.1111/j.14724669.2006.00059.x

Inskeep WP, Jay ZJ, Tringe SG, Herrgard MJ, Rusch DB, Co YMPS (2013) The YNP metagenome project: environmental parameters responsible for microbial distribution in the Yellowstone geothermal ecosystem Front Microbiol 4 doi:10.3389/fmicb.2013.00067

Inskeep WP, Macur RE, Harrison G, Bostick BC, Fendorf S (2004) Biomineralization of As(V)hydrous ferric oxyhydroxide in microbial mats of an acid-sulfate-chloride geothermal spring, Yellowstone National Park Geochim Cosmochim Ac 68:3141-3155 doi:10.1016/j.gca.2003.09.020

Jelen B, Giovannelli D, Falkowski PG, Vetriani C (2018) Elemental sulfur reduction in the deepsea vent thermophile, Thermovibrio ammonificans Environ Microbiol 20:2301-2316 doi:10.1111/1462-2920.14280

Johnson CM, Beard BL, Roden EE (2008) The iron isotope fingerprints of redox and biogeochemical cycling in modern and ancient Earth Annu Rev Earth Pl Sc 36:457-493 doi:10.1146/annurev.earth.36.031207.124139 
Johnson DB, Hallberg KB (2005) Acid mine drainage remediation options: a review Sci Total Environ 338:3-14 doi:10.1016/j.scitotenv.2004.09.002

Johnson DB, Kanao T, Hedrich S (2012) Redox transformations of iron at extremely low pH: fundamental and applied aspects Front Microbiol 3 doi:10.3389/fmicb.2012.00096

Kamyshny A (2009) Solubility of cyclooctasulfur in pure water and sea water at different temperatures Geochim Cosmochim Ac 73:6022-6028 doi:10.1016/j.gca.2009.07.003

Kamyshny A, Druschel G, Mansaray ZF, Farquhar J (2014) Multiple sulfur isotopes fractionations associated with abiotic sulfur transformations in Yellowstone National Park geothermal springs Geochem T 15:7 doi:10.1186/1467-4866-15-7

Kamyshny A, Goifman A, Rizkov D, Lev O (2003) Kinetics of disproportionation of inorganic polysulfides in undersaturated aqueous solutions at environmentally relevant conditions Aquat Geochem 9:291-304 doi:10.1023/B:AQUA.0000029023.07252.c3

Kamyshny A, Gun J, Rizkov D, Voitsekovski T, Lev O (2007) Equilibrium distribution of polysulfide ions in aqueous solutions at different temperatures by rapid single phase derivatization Environ Sci Technol 41:2395-2400 doi:10.1021/es062637+

Kaplan IR, Rittenberg SC (1962) Fractionation of isotopes in relation to the problem of elemental sulphur transport by micro-organisms Nature 194:1098 doi:10.1038/1941098a0

Kashefi K, Lovley DR (2000) Reduction of Fe(III), Mn(IV), and toxic metals at 100 degrees C by Pyrobaculum islandicum Appl Environ Microbiol 66:1050-1056 doi:10.1128/Aem.66.3.1050-1056.2000

Kashefi K, Lovley DR (2003) Extending the upper temperature limit for life Science 301:934934 doi:10.1126/science. 1086823

Kashefi K, Moskowitz BM, Lovley DR (2008a) Characterization of extracellular minerals produced during dissimilatory $\mathrm{Fe}(\mathrm{III})$ and $\mathrm{U}(\mathrm{VI})$ reduction at 100 degrees $\mathrm{C}$ by Pyrobaculum islandicum Geobiology 6:147-154 doi:10.1111/j.1472-4669.2007.00142.x

Kashefi K, Shelobolina ES, Elliott WC, Lovley DR (2008b) Growth of thermophilic and hyperthermophilic Fe (III)-reducing microorganisms on a ferruginous smectite as the sole electron acceptor Appl Environ Microbiol 74:251-258 doi:10.1128/Aem.01580-07

Kharaka YK, Thordsen JJ, White LD (2002) Isotope and chemical compositions of meteoric and thermal waters and snow from the greater Yellowstone National Park region. Geological Survey Menlo Park CA,

Kleinjan WE, de Keizer A, Janssen AJH (2005) Kinetics of the reaction between dissolved sodium sulfide and biologically produced sulfur Ind Eng Chem Res 44:309-317 doi: $10.1021 / \mathrm{ie} 049579 \mathrm{q}$ 
Kletzin A, Urich T, Muller F, Bandeiras TM, Gomes CM (2004) Dissimilatory oxidation and reduction of elemental sulfur in thermophilic Archaea J Bioenerg Biomembr 36:77-91 doi:10.1023/B:JOBB.0000019600.36757.8c

Klimmek O, Kroger A, Steudel R, Holdt G (1991) Growth of Wolinella succinogenes with polysulfide as terminal acceptor of phosphorylative electron-transport Arch Microbiol 155:177-182 doi:10.1007/Bf00248614

Kozubal M, Macur RE, Korf S, Taylor WP, Ackerman GG, Nagy A, Inskeep WP (2008) Isolation and distribution of a novel iron-oxidizing crenarchaeon from acidic geothermal springs in Yellowstone National Park Appl Environ Microbiol 74:942-949 doi:10.1128/Aem.01200-07

Kozubal MA et al. (2012) Microbial iron cycling in acidic geothermal springs of Yellowstone National Park: integrating molecular surveys, geochennical processes, and isolation of novel Fe-active microorganisms Front Microbiol 3:109 doi:10.3389/fmicb.2012.00109

Kraemer SM (2004) Iron oxide dissolution and solubility in the presence of siderophores Aquat Sci 66:3-18 doi:10.1007/s00027-003-0690-5

Langner HW, Jackson CR, Mcdermott TR, Inskeep WP (2001) Rapid oxidation of arsenite in a hot spring ecosystem, Yellowstone National Park Environ Sci Technol 35:3302-3309 doi:10.1021/es0105562

Laska S, Lottspeich F, Kletzin A (2003) Membrane-bound hydrogenase and sulfur reductase of the hyperthermophilic and acidophilic archaeon Acidianus ambivalens Microbiol-Sgm 149:2357-2371 doi:10.1099/mic.0.26455-0

Lindsay MR et al. (2018) Subsurface processes influence oxidant availability and chemoautotrophic hydrogen metabolism in Yellowstone hot springs Geobiology 16:674692 doi:10.1111/gbi. 12308

Liu YM et al. (2014) A trans-outer membrane porin-cytochrome protein complex for extracellular electron transfer by Geobacter sulfurreducens PCA Env Microbiol Rep 6:776-785 doi:10.1111/1758-2229.12204

Lorenson GW (2006) Application of in situ au-amalgam microelectrodes in yellowstone national park to guide microbial sampling: an investigation into arsenite and polysulfide detection to define microbial habitats. University of Vermont

Lovley DR (1991) Dissimilatory Fe(III) and Mn(IV) Reduction Microbiol Rev 55:259-287

Lovley DR (2004) Potential role of dissimilatory iron reduction in the early evolution of microbial respiration. In: Seckbach J (ed) Origins. Genesis, evolution and diversity of life. Springer, Dordrecht, pp 299-313

Lovley DR, Holmes DE, Nevin KP (2004) Dissimilatory Fe(III) and Mn(IV) reduction Adv Microb Physiol 49:219-286 doi:10.1016/S0065-2911(04)49005-5 
Lowenstern JB, Bergfeld D, Evans WC, Hunt AG (2015) Origins of geothermal gases at Yellowstone J Volcanol Geoth Res 302:87-101 doi:10.1016/j.jvolgeores.2015.06.010

Lowenstern JB, Bergfeld D, Evans WC, Hurwitz S (2012) Generation and evolution of hydrothermal fluids at Yellowstone: Insights from the Heart Lake Geyser Basin Geochemistry, Geophysics, Geosystems 13:1-20

Luther GW, Findlay AJ, MacDonald DJ, Owings SM, Hanson TE, Beinart RA, Girguis PR (2011) Thermodynamics and kinetics of sulfide oxidation by oxygen: a look at inorganically controlled reactions and biologically mediated processes in the environment Front Microbiol 2:62 doi:10.3389/fmicb.2011.00062

Lyons TW, Reinhard CT, Planavsky NJ (2014) The rise of oxygen in Earth's early ocean and atmosphere Nature 506:307-315 doi:10.1038/nature13068

Macur RE, Jay ZJ, Taylor W, Kozubal MA, Kocar BD, Inskeep WP (2013) Microbial community structure and sulfur biogeochemistry in mildly-acidic sulfidic geothermal springs in Yellowstone National Park Geobiology 11:86-99 doi:10.1111/gbi.12015

Magnuson TS, Isoyama N, Hodges-Myerson AL, Davidson G, Maroney MJ, Geesey GG, Lovley DR (2001) Isolation, characterization and gene sequence analysis of a membraneassociated $89 \mathrm{kDa} \mathrm{Fe}(\mathrm{III})$ reducing cytochrome $c$ from Geobacter sulfurreducens Biochem J 359:147-152 doi:10.1042/0264-6021:3590147

Malvankar NS et al. (2015) Structural basis for metallic-like conductivity in microbial nanowires mBio 6 doi:10.1128/mBio.00084-15

Marsili E, Baron DB, Shikhare ID, Coursolle D, Gralnick JA, Bond DR (2008) Shewanella secretes flavins that mediate extracellular electron transfer P Natl Acad Sci USA 105:3968-3973 doi:10.1073/pnas.0710525105

McKenzie WF, Truesdell A (1977) Geothermal reservoir temperatures estimated from the oxygen isotope compositions of dissolved sulfate and water from hot springs and shallow drillholes Geothermics 5:51-61

Miller SL, Bada JL (1988) Submarine hot springs and the origin of life Nature 334:609-611 doi: $10.1038 / 334609 \mathrm{a} 0$

Millero FJ (1986) The pH of estuarine waters Limnol Oceanogr 31:839-847 doi:10.4319/lo.1986.31.4.0839

Morgan B, Lahav O (2007) The effect of $\mathrm{pH}$ on the kinetics of spontaneous Fe(II) oxidation by $\mathrm{O}_{2}$ in aqueous solution - basic principles and a simple heuristic description Chemosphere 68:2080-2084 doi:10.1016/j.chemosphere.2007.02.015

Morris J (1975) The physiology of obligate anaerobiosis Adv Microbial Physiol 12:169-246 doi:10.1016/S0065-2911(08)60282-9 
Muyzer G, Stams AJM (2008) The ecology and biotechnology of sulphate-reducing bacteria Nat Rev Microbiol 6:441-454 doi:10.103 8/nrmicro1892

Myers JM, Myers CR (2001) Role for outer membrane cytochromes OmcA and OmcB of Shewanella putrefaciens MR-1 in reduction of manganese dioxide Appl Environ Microbiol 67:260-269 doi:10.1128/Aem.67.1.260-269.2001

Nealson KH, Scott J (2006) Ecophysiology of the genus Shewanella. In: Dworkin M, Falkow S, Rosenberg E, Schleifer K-H, Stackebrandt E (eds) Prokaryotes: A Handbook on the Biology of Bacteria. Springer, New York, pp 1133-1151

Newman DK, Kolter R (2000) A role for excreted quinones in extracellular electron transfer Nature 405:94-97 doi:10.1038/35011098

Nisbet EG, Sleep NH (2001) The habitat and nature of early life Nature 409:1083-1091 doi: $10.1038 / 35059210$

Nordstrom DK, Ball JW, McCleskey RB (2004) Oxidation reactions for reduced Fe, As, and S in thermal outflows of Yellowstone National Park: biotic or abiotic? In: Wanty RB, Seal II RR (eds) Water-Rock Interaction. Taylor \& Francis Group, London, UK,

Nordstrom DK, Ball JW, McCleskey RB (2005) Ground water to surface water: chemistry of thermal outflows in Yellowstone National Park. In: Inskeep WP, McDermott T (eds) Geothermal biology and geochemistry in Yellowstone National Park. Montana State University Publications, Bozeman, Montana, pp 73-94

Nordstrom DK, McCleskey RB, Ball JW (2009) Sulfur geochemistry of hydrothermal waters in Yellowstone National Park: IV Acid-sulfate waters Appl Geochem 24:191-207 doi:10.1016/j.apgeochem.2008.11.019

Pace NR (1997) A molecular view of microbial diversity and the biosphere Science 276:734-740 doi:10.1126/science.276.5313.734

Philippot P, Van Zuilen M, Lepot K, Thomazo C, Farquhar J, Van Kranendonk MJ (2007) Early archaean microorganisms preferred elemental sulfur, not sulfate Science 317:1534-1537 doi:10.1126/science. 1145861

Pierson BK, Parenteau MN (2000) Phototrophs in high iron microbial mats: microstructure of mats in iron-depositing hot springs FEMS Microbiol Ecol 32:181-196

Power JF et al. (2018) Microbial biogeography of 925 geothermal springs in New Zealand Nat Commun 9:2876 doi:10.1038/s41467-018-05020-y

Reguera G, McCarthy KD, Mehta T, Nicoll JS, Tuominen MT, Lovley DR (2005) Extracellular electron transfer via microbial nanowires Nature 435:1098-1101 doi:10.1038/nature03661 
Reysenbach AL et al. (2006) A ubiquitous thermoacidophilic archaeon from deep-sea hydrothermal vents Nature 442:444-447 doi:10.1038/nature04921

Richardson DJ (2000) Bacterial respiration: a flexible process for a changing environment Microbiol-Uk 146:551-571 doi:10.1099/00221287-146-3-551

Rickard D (1997) Kinetics of pyrite formation by the $\mathrm{H}_{2} \mathrm{~S}$ oxidation of iron (II) monosulfide in aqueous solutions between 25 and 125 degrees $\mathrm{C}$ : The rate equation Geochim Cosmochim Ac 61:115-134 doi:10.1016/S0016-7037(96)00321-3

Rickard D, Luther GW, 3rd (2007) Chemistry of iron sulfides Chem Rev 107:514-562 doi: $10.1021 / \mathrm{cr} 0503658$

Roberts JA, Kenward PA, Fowle DA, Goldstein RH, Gonzalez LA, Moore DS (2013) Surface chemistry allows for abiotic precipitation of dolomite at low temperature P Natl Acad Sci USA 110:14540-14545 doi:10.1073/pnas.1305403110

Roden EE, Zachara JM (1996) Microbial reduction of crystalline iron(III) oxides: Influence of oxide surface area and potential for cell growth Environ Sci Technol 30:1618-1628 doi:10.1021/es9506216

Rothschild LJ, Mancinelli RL (2001) Life in extreme environments Nature 409:1092-1101 doi:10.1038/35059215

Russell MJ, Martin W (2004) The rocky roots of the acetyl-CoA pathway Trends in biochemical sciences 29:358-363 doi:10.1016/j.tibs.2004.05.007

Rye RO, Truesdell AH (2007) The question of recharge to the deep thermal reservoir underlying the geysers and hot springs of Yellowstone National Park. In: Morgan LA (ed) Integrated geoscience studies in the greater Yellowstone area-Volcanic, tectonic, and hydrothermal processes in the Yellowstone geoecosystem. U.S. Geological Survey Professional Paper

Schauder R, Kröger A (1993) Bacterial sulphur respiration Arch Microbiol 159:491-497 doi:10.1007/bf00249025

Schauder R, Muller E (1993) Polysulfide as a possible substrate for sulfur-reducing bacteria Arch Microbiol 160:377-382

Schut GJ, Boyd ES, Peters JW, Adams MWW (2013) The modular respiratory complexes involved in hydrogen and sulfur metabolism by heterotrophic hyperthermophilic archaea and their evolutionary implications FEMS Microbiol Rev 37:182-203 doi:10.1111/j.1574-6976.2012.00346.x

Schut GJ, Bridger SL, Adams MWW (2007) Insights into the metabolism of elemental sulfur by the hyperthermophilic archaeon Pyrococcus furiosus: Characterization of a coenzyme Adependent NAD(P)H sulfur oxidoreductase J Bacteriol 189:4431-4441 doi:10.1128/Jb.00031-07 
Schut GJ, Zadvornyy O, Wu CH, Peters JW, Boyd ES, Adams MWW (2016) The role of geochemistry and energetics in the evolution of modern respiratory complexes from a proton-reducing ancestor BBA-Bioenergetics 1857:958-970

doi:10.1016/j.bbabio.2016.01.010

Schwartzman DW, Lineweaver CH (2004) The hyperthermophilic origin of life revisited Biochem Soc T 32:168-171 doi:10.1042/Bst0320168

Segerer A, Neuner A, Kristjansson JK, Stetter KO (1986) Acidianus infernus gen. nov. sp. nov., and Acidianus brierleyi Comb. nov.: Facultatively aerobic, extremely acidophilic thermophilic sulfur-metabolizing archaebacteria Int J Syst Bacteriol 36:559-564 doi:10.1099/00207713-36-4-559

Shi L et al. (2016) Extracellular electron transfer mechanisms between microorganisms and minerals Nat Rev Microbiol 14:651-662 doi:10.1038/nrmicro.2016.93

Shi L, Squier TC, Zachara JM, Fredrickson JK (2007) Respiration of metal (hydr)oxides by Shewanella and Geobacter: a key role for multihaem $c$-type cytochromes Mol Microbiol 65:12-20 doi:10.1111/j.1365-2958.2007.05783.x

Shi LA, Richardson DJ, Wang ZM, Kerisit SN, Rosso KM, Zachara JM, Fredrickson JK (2009) The roles of outer membrane cytochromes of Shewanella and Geobacter in extracellular electron transfer Env Microbiol Rep 1:220-227 doi:10.1111/j.1758-2229.2009.00035.x

Shock EL, Holland M, Meyer-Dombard D, Amend JP, Osburn GR, Fischer TP (2010) Quantifying inorganic sources of geochemical energy in hydrothermal ecosystems, Yellowstone National Park, USA Geochim Cosmochim Ac 74:4005-4043 doi:10.1016/j.gca.2009.08.036

Shock EL, McCollom T, Schulte MD (1995) The emergence of metabolism from within hydrothermal systems. In: Wiegel J, Adams MWW (eds) Thermophiles. The keys to molecular evolution and the origin of life? CRC Press, pp 59-76

Slobodkin A, Reysenbach AL, Strutz N, Dreier M, Wiegel J (1997) Thermoterrabacterium ferrireducens gen nov, sp nov, a thermophilic anaerobic dissimilatory Fe(III)-reducing bacterium from a continental hot spring Int J Syst Bacteriol 47:541-547 doi:Doi $10.1099 / 00207713-47-2-541$

Slobodkin AI (2005) Thermophilic microbial metal reduction Microbiology + 74:501-514 doi:10.1007/s1 1021-005-0096-6

Slobodkin AI, Reysenbach AL, Slobodkina GB, Baslerov RV, Kostrikina NA, Wagner ID, Bonch-Osmolovskaya EA (2012) Thermosulfurimonas dismutans gen. nov., sp nov., an extremely thermophilic sulfur-disproportionating bacterium from a deep-sea hydrothermal vent Int J Syst Evol Micr 62:2565-2571 doi:10.1099/ijs.0.034397-0

Slobodkin AI, Tourova TP, Kuznetsov BB, Kostrikina NA, Chernyh NA, Bonch-Osmolovskaya EA (1999) Thermoanaerobacter siderophilus sp. nov., a novel dissimilatory Fe(III)- 
reducing, anaerobic, thermophilic bacterium Int J Syst Bacteriol 49:1471-1478

doi:10.1099/00207713-49-4-1471

Slobodkina GB, Panteleeva AN, Sokolova TG, Bonch-Osmolovskaya EA, Slobodkin AI (2012) Carboxydocella manganica sp. nov., a thermophilic, dissimilatory $\mathrm{Mn}(\mathrm{IV})$ - and Fe(III)reducing bacterium from a Kamchatka hot spring Int J Syst Evol Micr 62:890-894 doi:10.1099/ijs.0.027623-0

Smith RB, Braile LW (1994) The Yellowstone hotspot J Volcanol Geoth Res 61:121-187 doi:10.1016/0377-0273(94)90002-7

Sorokin DY et al. (2001) Thioalkalimicrobium aerophilum gen. nov., sp. nov., and Thioalkalimicrobium sibericum sp. nov., and Thioalkalivibrio versutus gen. nov., sp. nov., Thioalkalivibrio nitratis sp. nov., and Thioalkalivibrio denitrificans sp. nov., novel obligately alkaliphilic and obligately chemolithoautotrophic sulfur-oxidizing bacteria from soda lakes Int J Syst Evol Micr 51:565-580 doi:10.1099/00207713-51-2-565

Stetter KO, Fiala G, Huber G, Huber R, Segerer A (1990) Hyperthermophilic microorganisms Fems Microbiol Lett 75:117-124 doi:doi:10.1111/j.1574-6968.1990.tb04089.x

Stetter KO, Gaag G (1983) Reduction of molecular sulphur by methanogenic bacteria Nature 305:309 doi:10.1038/305309a0

Steudel R (1996) Mechanism for the formation of elemental sulfur from aqueous sulfide in chemical and microbiological desulfurization processes Ind Eng Chem Res 35:1417-1423 doi:10.1021/ie950558t

Steudel R, Eckert B (2003) Solid sulfur allotropes. In: Steudel R (ed) Elemental Sulfur and Sulfur-Rich Compounds I, vol 230. Springer, Berlin, Heidelberg, pp 1-79

Surkov AV, Böttcher ME, Kuever J (2012) Sulphur isotope fractionation during the reduction of elemental sulphur and thiosulphate by Dethiosulfovibrio spp Isotopes Environ Health Stud 48:65-75 doi:10.1080/10256016.2011.626525

Thauer RK, Jungermann K, Decker K (1977) Energy conservation in chemotropic anaerobic Bacteria Bacteriol Rev 41:100-180

Trouwborst RE, Johnston A, Koch G, Luther GW, Pierson BK (2007) Biogeochemistry of Fe(II) oxidation in a photosynthetic microbial mat: Implications for Precambrian Fe(II) oxidation Geochim Cosmochim Ac 71:4629-4643 doi:10.1016/j.gca.2007.07.018

Truesdell AH, Fournier RO (1976) Conditions in the deeper parts of the hot spring systems of Yellowstone National Park, Wyoming. US Geological Survey,

Urschel MR, Hamilton TL, Roden EE, Boyd ES (2016) Substrate preference, uptake kinetics and bioenergetics in a facultatively autotrophic, thermoacidophilic crenarchaeote FEMS Microbiol Ecol 92:fiw069 doi:10.1093/femsec/fiw069 
Urschel MR, Kubo MD, Hoehler TM, Peters JW, Boyd ES (2015) Carbon source preference in chemosynthetic hot spring communities Appl Environ Microbiol 81:3834-3847 doi:10.1128/Aem.00511-15

Van Kranendonk MJ (2006) Volcanic degassing, hydrothermal circulation and the flourishing of early life on Earth: A review of the evidence from c. 3490-3240 Ma rocks of the Pilbara Supergroup, Pilbara Craton, Western Australia Earth-Science Reviews 74:197-240 doi:https://doi.org/10.1016/j.earscirev.2005.09.005

Vargas M, Kashefi K, Blunt-Harris EL, Lovley DR (1998) Microbiological evidence for Fe(III) reduction on early Earth Nature 395:65-67 doi:10.1038/25720

Vasconcelos C, Mckenzie JA, Bernasconi S, Grujic D, Tien AJ (1995) Microbial mediation as a possible mechanism for natural dolomite formation at low-temperatures Nature 377:220222 doi: $10.1038 / 377220 \mathrm{a} 0$

von Canstein H, Ogawa J, Shimizu S, Lloyd JR (2008) Secretion of flavins by Shewanella species and their role in extracellular electron transfer Appl Environ Microbiol 74:615623 doi:10.1128/Aem.01387-07

Wachtershauser G (1988) Pyrite formation, the 1st energy-source for life - a hypothesis Syst Appl Microbiol 10:207-210 doi:10.1016/S0723-2020(88)80001-8

Wachtershauser G (1992) Groundworks for an evolutionary biochemistry - the iron sulfur world Prog Biophys Mol Bio 58:85-201 doi:10.1016/0079-6107(92)90022-X

Wachtershauser G (2006) From volcanic origins of chemoautotrophic life to Bacteria, Archaea and Eukarya Philos T R Soc B 361:1787-1806 doi:10.1098/rstb.2006.1904

Wade ML, Agresti DG, Wdowiak TJ, Armendarez LP, Farmer JD (1999) A Mossbauer investigation of iron-rich terrestrial hydrothermal vent systems: Lessons for Mars exploration J Geophys Res-Planet 104:8489-8507 doi:10.1029/1998je900049

Weber KA, Achenbach LA, Coates JD (2006) Microorganisms pumping iron: anaerobic microbial iron oxidation and reduction Nat Rev Microbiol 4:752-764 doi: $10.1038 /$ nrmicro1490

White DE, Hutchinson RA, Keith TE (1988) Geology and remarkable thermal activity of Norris Geyser Basin, Yellowstone National Park, Wyoming US Geol Surv, Prof Pap;(United States) 75

White DE, Muffler LJP, Truesdell AH (1971) Vapor-dominated hydrothermal systems compared with hot-water systems Econ Geol 66:75-97 doi:10.2113/gsecongeo.66.1.75

Wu CH, Schut GJ, Poole FL, Haja DK, Adams MWW (2018) Characterization of membranebound sulfane reductase: A missing link in the evolution of modern day respiratory complexes J Biol Chem 293:16687-16696 doi:10.1074/jbc.RA118.005092 
Wu LL, Brucker RP, Beard BL, Roden EE, Johnson CM (2013) Iron isotope characteristics of hot Springs at Chocolate Pots, Yellowstone National Park Astrobiology 13:1091-1101 doi:10.1089/ast.2013.0996

$\mathrm{Xu}$ Y, Schoonen MAA (1995) The stability of thiosulfate in the presence of pyrite in lowtemperature aqueous-solutions Geochim Cosmochim Ac 59:4605-4622 doi:10.1016/0016-7037(95)00331-2

Xu Y, Schoonen MAA, Nordstrom DK, Cunningham KM, Ball JW (1998) Sulfur geochemistry of hydrothermal waters in Yellowstone National Park: I. The origin of thiosulfate in hot spring waters Geochim Cosmochim Ac 62:3729-3743 doi:10.1016/S00167037(98)00269-5

Yoshida N, Nakasato M, Ohmura N, Ando A, Saiki H, Ishii M, Igarashi Y (2006) Acidianus manzaensis sp. nov., a novel thermoacidophilic archaeon growing autotrophically by the oxidation of $\mathrm{H}_{2}$ with the reduction of $\mathrm{Fe}^{3+}$ Curr Microbiol 53:406-411 doi:10.1007/s00284-006-0151-1

Zerkle AL, Farquhar J, Johnston DT, Cox RP, Canfield DE (2009) Fractionation of multiple sulfur isotopes during phototrophic oxidation of sulfide and elemental sulfur by a green sulfur bacterium Geochim Cosmochim Ac 73:291-306 doi:https://doi.org/10.1016/j.gca.2008.10.027

Zhang FF, Xu HF, Konishi H, Kemp JM, Roden EE, Shen ZZ (2012) Dissolved sulfidecatalyzed precipitation of disordered dolomite: Implications for the formation mechanism of sedimentary dolomite Geochim Cosmochim Ac 97:148-165 doi:10.1016/j.gca.2012.09.008

Zhang FF, Xu HF, Shelobolina ES, Konishi H, Converse B, Shen ZZ, Roden EE (2015) The catalytic effect of bound extracellular polymeric substances excreted by anaerobic microorganisms on Ca-Mg carbonate precipitation: Implications for the "dolomite problem" Am Mineral 100:483-494 doi:10.2138/am-2015-4999

Zhang JZ, Millero FJ (1993) The Products from the oxidation of $\mathrm{H}_{2} \mathrm{~S}$ in seawater Geochim Cosmochim Ac 57:1705-1718 doi:10.1016/0016-7037(93)90108-9 


\section{Figures and Figure Legends}

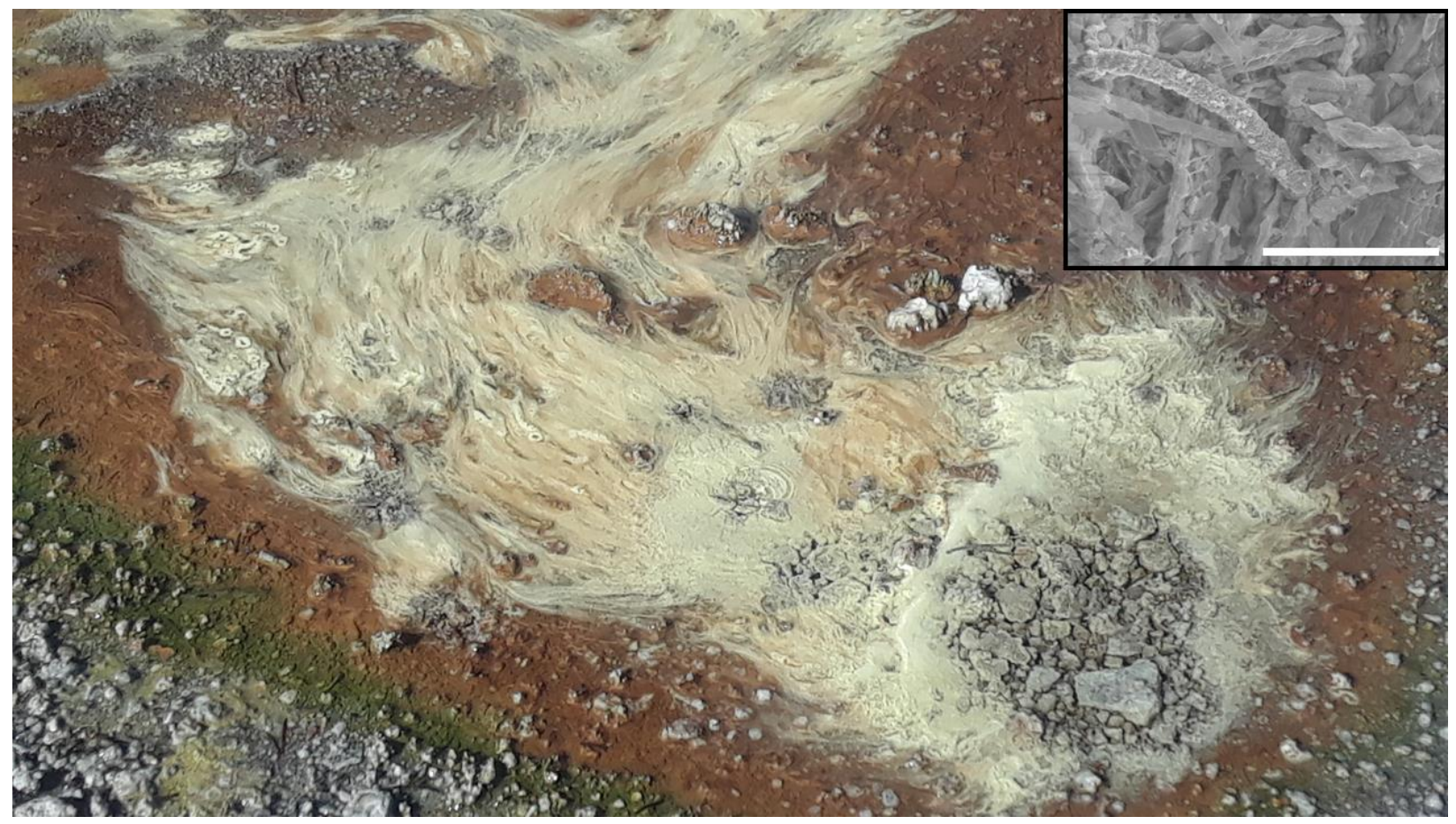

Figure 1. Filamentous and sessile microbial communities growing in close association with minerals in a sulfur-rich, acidic hot spring in Yellowstone National Park, Wyoming, U.S.A. The source of the hot spring $\left(73^{\circ} \mathrm{C}\right)$ is depicted by the grey geyserite minerals at the lower right-hand corner of the image. The spring water cools as it flows away from its source, creating distinct thermal and chemical zones corresponding to differences in microbiological activity and mineral precipitation. The yellow color represents precipitated elemental sulfur $\left(\mathrm{S}^{\circ}\right)$ that coats the microbial filaments. The brown colored minerals represent iron (hydr)oxides while the green color is due to pigments produced by photosynthetic algal communities. The temperature of the transition between the yellow filamentous communities and the brown iron (hydr)oxides is $\sim 65^{\circ} \mathrm{C}$ whereas the temperature of the transition between the brown iron (hydr)oxides and the phototrophic mats is $\sim 52-54^{\circ} \mathrm{C}$. Thus, the transition from chemosynthetic to photosynthetic communities takes place at $\sim 52-54^{\circ} \mathrm{C}$ in this spring. Photo by Maximiliano Amenabar. Inset, scanning electron microscopic image of filamentous sulfur communities. Note the presence of rhombic $\mathrm{S}^{\circ}$ crystals. The scale bar is $30 \mu \mathrm{m}$. Image by Eric Boyd. 


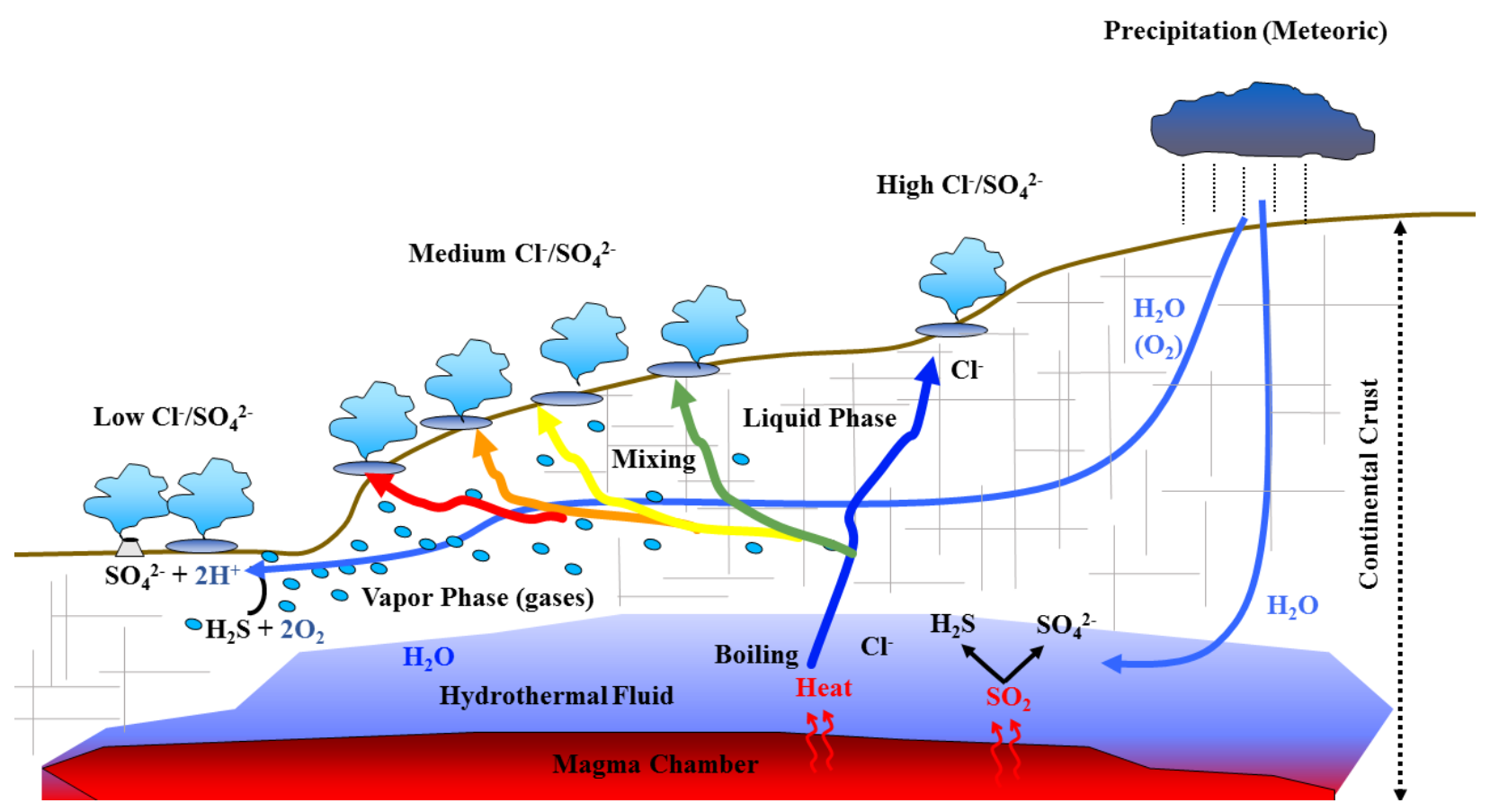

Figure 2. A model describing the development of geochemical variation in continental, volcanic environments such as Yellowstone National Park (YNP), Wyoming, U.S.A. Oxygen-rich meteoric water (precipitation) can infiltrate the subsurface where it interacts with hot rocks. Less dense heated waters then can ascend to the surface through flow paths along fractured and faulted bedrock. During its ascent to the surface, hot fluids interact with bedrock, allowing for leaching of minerals and acquisition of solutes. Ascending water can undergo decompressional boiling that can separate fluids into a liquid and a vapor phase (phase separation). Ions such as $\mathrm{Cl}^{-}$behave conservatively and remain in the liquid phase whereas volatiles, including hydrogen sulfide $\left(\mathrm{H}_{2} \mathrm{~S}\right)$, partition into the vapor phase. This vapor can also ascend to the surface and condense with oxygen-rich meteoric water that can drive the production of sulfuric acid and the acidification of hydrothermal waters. Phase separation is thought to be a multi-phase process that may affect the amount of sulfide in vapor- or liquid phase-influenced waters and thus the extent of possible acidification of those waters. In the schematic, multi-stage phase separation is depicted by arrow color with blue depicting circumneutral, $\mathrm{Cl}^{-}$rich waters and green, yellow, orange, and red depicting progressively more acidic waters. Condensation of vapor with perched aquifers that are progressively more acidified could favor speciation of $\mathrm{H}_{2} \mathrm{~S} / \mathrm{HS}^{-}(\mathrm{pKa}=6.5$ at $100^{\circ} \mathrm{C}$ ) to the protonated form, thereby increasing the amount that can be volatized in subsequent phase separation events. If sulfide input is the primary driver of acidification of spring waters, as has been suggested, this could potentially lead to acidification of waters in certain geographic locations or springs, as is has beensuggested for the Norris Geyser Basin in YNP (see text for details). 


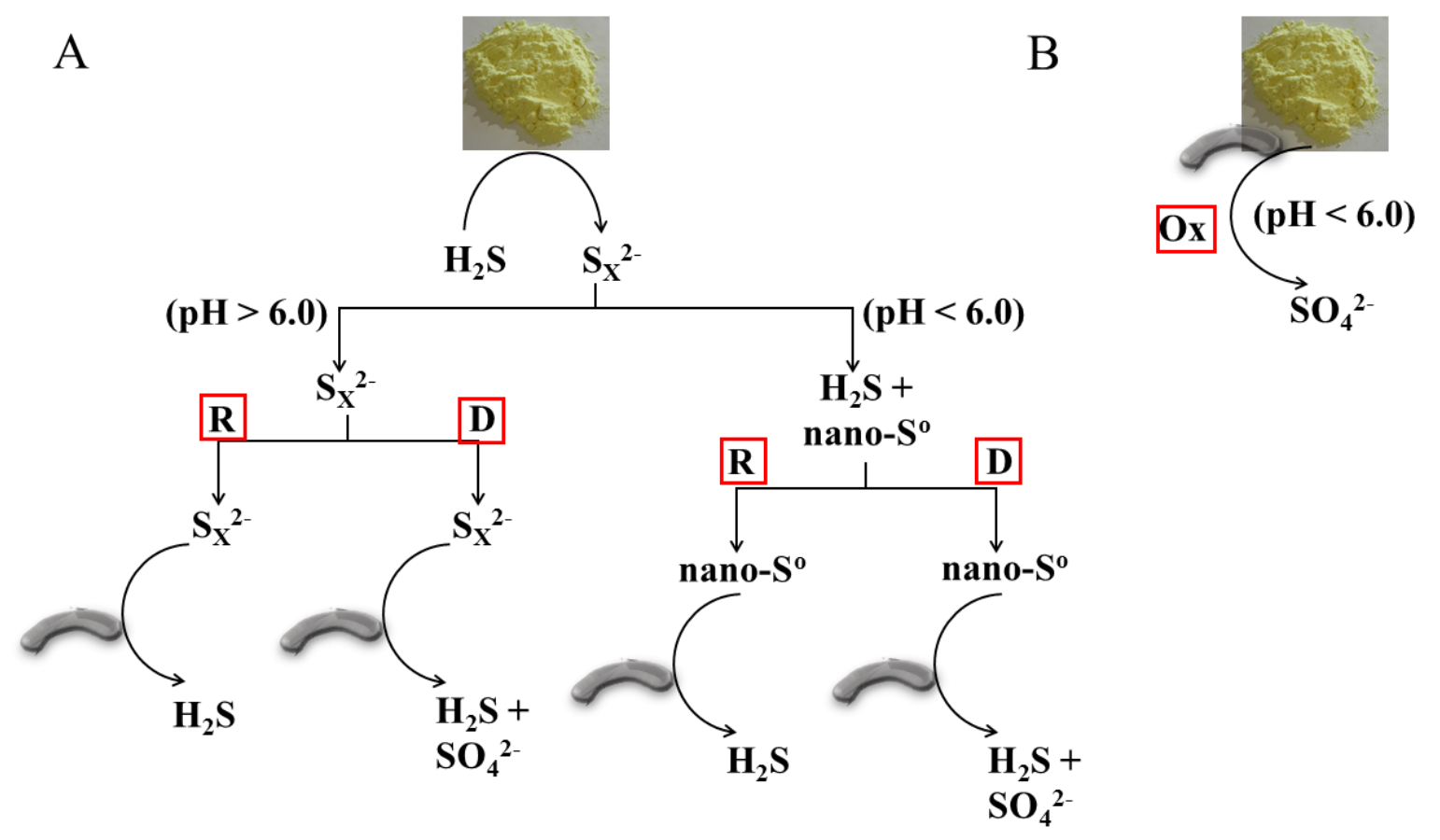

Figure 3. Schematic describing the primary reactions involved in generating bioavailable nanoparticulate elemental sulfur $\left(\mathrm{S}^{\circ}\right)$ or polysulfide $\left(\mathrm{S}_{\mathrm{x}}{ }^{2-}\right)$ as a substrate for reduction $(\mathrm{R})$, oxidation (Ox), or disproportionation (D) of bulk $\mathrm{S}^{\circ}$ (depicted by image of $\alpha-\mathrm{S}^{\circ}$ powder) as a function of environmental $\mathrm{pH}$. (A) Schematic illustrating $\mathrm{S}^{\circ}$ reduction or disproportionation under acidic $(\mathrm{pH}<6.0)$ or circumneutral to alkaline $(\mathrm{pH}>6.0)$ conditions. Note that reduction or disproportionation is not thought to require direct access to bulk $\mathrm{S}^{\circ}$ due to a series of reactions that involve $\mathrm{H}_{2} \mathrm{~S} / \mathrm{HS}^{-}$that generate soluble nanoparticulate $\mathrm{S}^{\circ}(\mathrm{pH}<6.0)$ or $\mathrm{S}_{\mathrm{x}}{ }^{2-}(\mathrm{pH}>6.0)(\mathbf{B})$ Schematic illustrating $\mathrm{S}^{\circ}$ oxidation at acidic $\mathrm{pH}$. Acidophilic organisms that oxidize $\mathrm{S}^{\circ}$ are thought to require direct contact with the bulk mineral since substrates capable of driving its solubilization via reactions described in $(\mathbf{A})\left(\right.$ e.g., $\left.\mathrm{H}_{2} \mathrm{~S} / \mathrm{HS}^{-}\right)$tend to not accumulate in oxidized environments. Oxidation of sulfur is not depicted at circumneutral to alkaline conditions since it is unlikely that $\mathrm{S}^{\circ}$ will accumulate under these conditions given that the intermediates that lend to $\mathrm{S}^{\circ}$ formation via $\mathrm{H}_{2} \mathrm{~S} / \mathrm{HS}^{-}$oxidation (e.g., $\mathrm{S}_{2} \mathrm{O}_{3}{ }^{2-}$ ) are stable. Cells are depicted as grey vibrio shapes. 


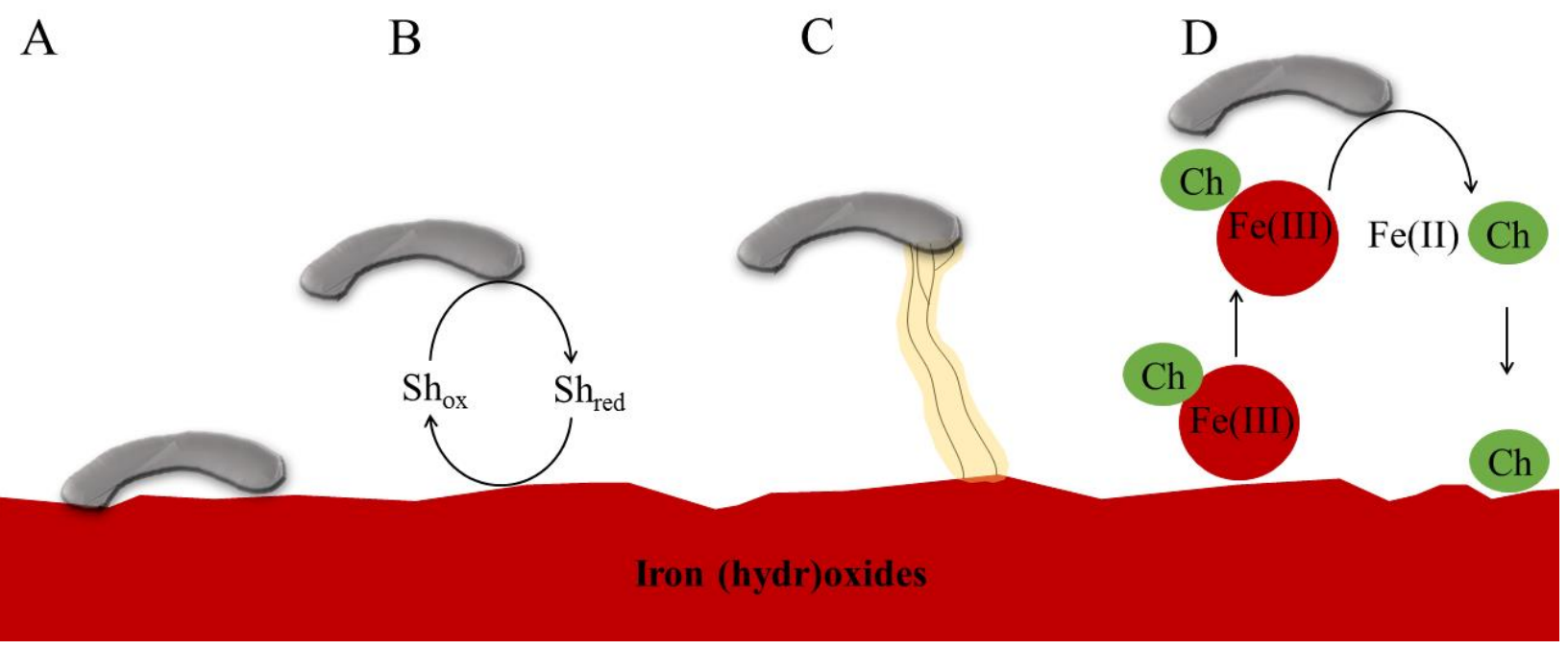

Figure 4. Schematic illustrating the four described mechanisms for electron transport to iron (hydr)oxides (illustrated by red substrate) during dissimilatory iron reduction (DIR). Cells are depicted by grey vibrio shapes. The four describing mechanisms of DIR include (A) direct electron transfer to iron (hydr)oxides, (B) the involvement of compounds (e.g., flavins) that shuttle electrons to iron (hydr)oxides, (C) the involvement of extracellular appendages (e.g., nanowires) as a conductive matrix for electron transport to iron (hydr)oxides, and (D) the involvement of chelators (green circles) that solubilize iron (hydr)oxides for subsequent reduction. 